Article

\title{
Lithogeochemistry of the Mid-Ocean Ridge Basalts near the Fossil Ridge of the Southwest Sub-Basin, South China Sea
}

\author{
Kai Sun, Tao Wu, Xuesong Liu, Xue-Gang Chen *(D) and Chun-Feng Li \\ Ocean College, Zhejiang University, Zhoushan 316021, China; 21734043@zju.edu.cn (K.S.); \\ wutaocug@126.com (T.W.); 21734039@zju.edu.cn (X.L.); cfli@zju.edu.cn (C.-F.L.) \\ * Correspondence: chenxg83@zju.edu.cn
}

Received: 27 April 2020; Accepted: 18 May 2020; Published: 20 May 2020

check for updates

\begin{abstract}
Mid-ocean ridge basalts (MORB) in the South China Sea (SCS) record deep crust-mantle processes during seafloor spreading. We conducted a petrological and geochemical study on the MORBs obtained from the southwest sub-basin of the SCS at site U1433 and U1434 of the International Ocean Discovery Program (IODP) Expedition 349. Results show that MORBs at IODP site U1433 and U1434 are unaffected by seawater alteration, and all U1433 and the bulk of U1434 rocks belong to the sub-alkaline low-potassium tholeiitic basalt series. Samples collected from site U1433 and U1434 are enriched mid-ocean ridge basalts (E-MORBs), and the U1434 basalts are more enriched in incompatible elements than the U1433 samples. The SCS MORBs have mainly undergone the fractional crystallization of olivine, accompanied by the relatively weak fractional crystallization of plagioclase and clinopyroxene during magma evolution. The magma of both sites might be mainly produced by the high-degree partial melting of spinel peridotite at low pressures. The degree of partial melting at site U1434 was lower than at U1433, ascribed to the relatively lower spreading rate. The magmatic source of the southwest sub-basin basalts may be contaminated by lower continental crust and contributed by recycled oceanic crust component during the opening of the SCS.
\end{abstract}

Keywords: South China Sea; mid-ocean ridge basalt; geochemistry; magmatism; magma source

\section{Introduction}

The mid-ocean ridge marks the spreading center of Earth's plate tectonics. Due to the depressurization and subsequent partial melting of the ascending mantle materials, basaltic magma emanates from the mid-ocean ridge. The magma is then cooled by seawater to form mid-ocean ridge basalt (MORB). MORB carries important information about the composition of the upper mantle [1]. In addition, basaltic magma may experience magmatic mixing and fractional crystallization during ascending and migration, information of which is also recorded in the MORBs [2-4]. Therefore, MORBs are key to understanding the magma evolution in spreading centers [5]. The South China Sea (SCS) is one of the most important marginal seas in the Western Pacific. Recovering MORBs from the SCS was a challenge [6-9] because thick sediments cover the seafloor of the SCS basin [10]. In 2014, the International Ocean Discovery Program (IODP) Expedition 349 drilled through the overlying sediment and successfully retrieved SCS MORBs from the site U1431 (eastern sub-basin), U1433 and U1434 (southwest sub-basin) for the first time [11].

These SCS MORBs offered scientists a great opportunity to study the geochemical nature of the sub-ridge mantle and the evolution of the SCS. Most research focused on the MORBs recovered from the Site U1431 located at the east sub-basin of the SCS [12,13]. Zhang et al. [14] analyzed the major elements, trace elements and $\mathrm{Sr}-\mathrm{Nd}-\mathrm{Pb}-\mathrm{Hf}$ isotopes of U1431 basalts, and figured that the east sub-basin consists 
of both normal (N)-MORB-type and enriched (E)-MORB-type basalts. Through modeling the influences of Hainan mantle plume and lower continental crust based on $\mathrm{Sr}-\mathrm{Nd}-\mathrm{Pb}-\mathrm{Hf}$ isotope compositions, the origin of Indian-type basalts in the East sub-basin can be explained by the involvement of Hainan plume in the sub-ridge mantle during seafloor spreading. A lithogeochemical study on the U1431 basalts [15] revealed that an eclogite-/pyroxenite-rich component, possibly originated from the Hainan hotspot, played a fundamental role in the transition from spreading to intraplate volcanism of the dying spreading ridge of the SCS. In addition, the Al-in-olivine thermometer [16] demonstrated that anomalously high crystallization temperature of primitive olivine in the SCS MORB, corresponding to the high mantle potential temperature, is consistent with the plume-ridge interaction in the SCS.

Few studies investigated the MORBs from the site U1433 and U1434. Both U1433 and U1434 situate near the fossil spreading center of the Southwest Sub-Basin. U1434 is about $40 \mathrm{~km}$ to the northwest of U1433 (Figure 1). The MORBs of both sites are formed in the late stage of the seafloor spreading of the SCS. The age of the U1434 ( 16.3Ma) MORB is slightly younger than the age of the U1433 MORB ( 17.3 Ma) [12]. Both site U1433 and U1434 MORBs in the Southwest sub-basin are enriched (E)-MORB type basalts based on trace element compositions and are Indian-type MORBs based on $\mathrm{Sr}-\mathrm{Nd}-\mathrm{Pb}-\mathrm{Hf}$ isotope compositions [14]. The different trace element patterns, La/Sm ratios and $\mathrm{Sr}-\mathrm{Nd}-\mathrm{Pb}-\mathrm{Hf}$ isotopes indicated geochemical changes of magma before the cessation of seafloor spreading [14]. Based on Sr-Nd-Pb-Hf isotope compositions, Zhang et al. [14] suggested that the sub-ridge mantle of the southwest sub-basin was influenced by the Hainan plume and contaminated by lower continental crust during the continent rifting and opening of the South China Sea. Nevertheless, a comprehensive understanding of the seawater alteration, fractional crystallization, and petrological and mineralogical characteristics of the SCS basalts still requires in-depth investigation.

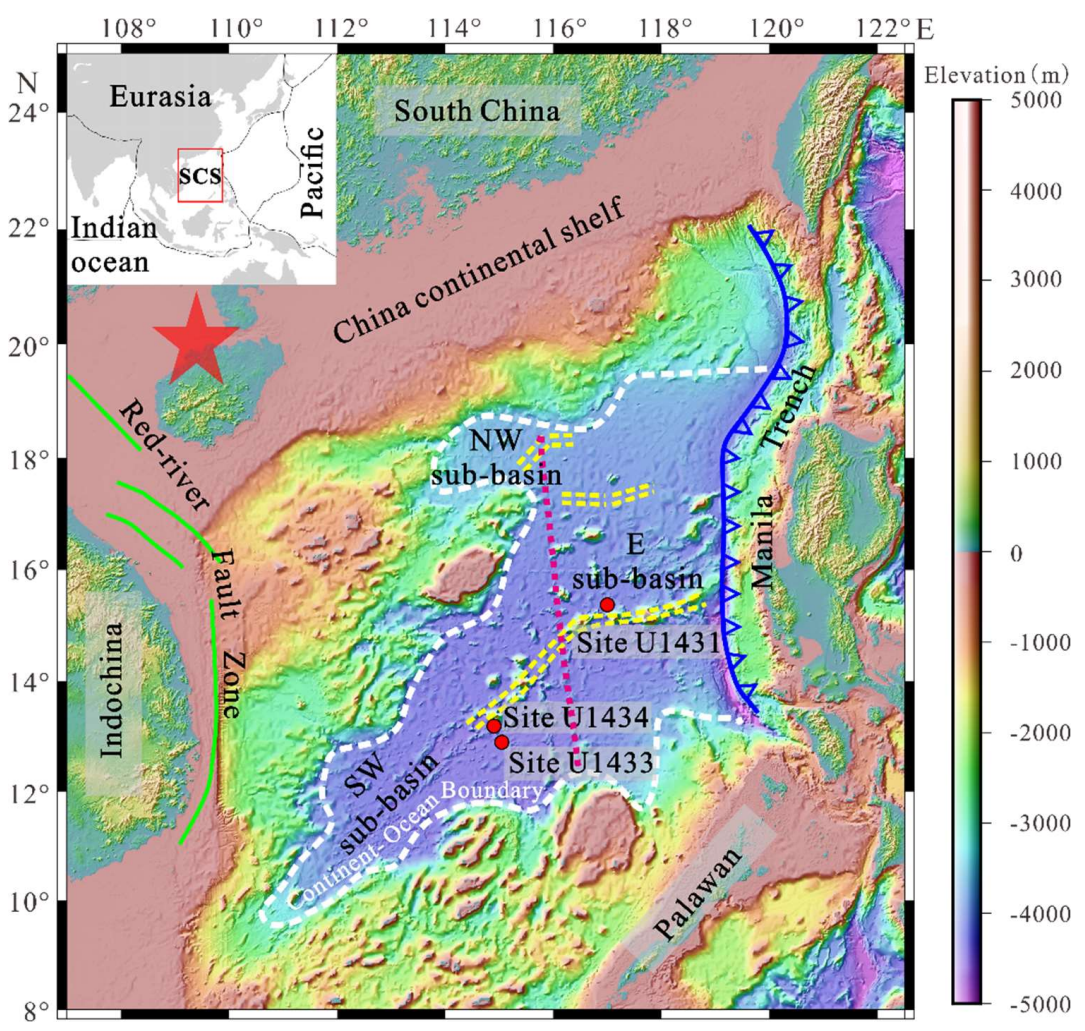

Figure 1. Geologic setting of the South China Sea (SCS) and the locations of Sites U1433 and U1434 of International Ocean Discovery Program (IODP) Expedition 349. Yellow dashed lines indicates the fossil spreading ridge, burgundy dashed line suggests the Zhongnan fault, white dashed line demonstrates continent-ocean boundary, green lines mark the red-river fault zone, blue line represents the Manila subduction zone and its subduction direction, and the red pentagram shows the inferred location of the Hainan plume [17,18]. 
In this study, we determined the mineral phases, chemical compositions, and optical microscopy of U1433 and U1434 MORBs using petrographic and microscopic observation, X-ray diffraction determination, and inductively coupled plasma mass spectrometry (ICP-MS) analysis. We seek to systematically study the magma formation and evolution processes in the southwest sub-basin of the SCS, including seawater alteration, fractional crystallization, mantle melting, and magmatic source, and also the possible influence of the Hainan plume to the magmatic activity of the mid-ocean ridge.

\section{Geological Setting}

The SCS is one of the world's largest marginal seas. It is located at the junction among the Indo-Australian plate, the Pacific plate, and the Eurasian plate (Figure 1) [19]. Despite its relatively young age and small size, the SCS experienced almost the entire Wilson cycle, from continental breakup to seafloor spreading and followed by subduction [11,20]. The eastern margin of the SCS is bounded by the Manila Trench, and the western margin is marked by the Red River fault zone [21,22]. The SCS basin can be divided into three sub-basins based on structural variations: the northwest sub-basin, the east sub-basin, and the southwest sub-basin [23]. The Zhongnan fault extending from north to south (Figure 1) separates the SCS into an east sub-basin and a southwest sub-basin [24]. Seafloor magnetic anomaly data indicated that the spreading time was 33-15.5 Ma at the east sub-basin and 24-16 Ma at the southwest sub-basin [24]. During the Cenozoic, the SCS underwent three episodes of seafloor spreading, and left three fossil spreading centers within the basin: the first one is oriented $\mathrm{E}-\mathrm{W}$ in the northwest (NW) sub-basin (near the present $18^{\circ} \mathrm{N}$ ); the second one is oriented E-W in the east sub-basin (near the present $17^{\circ} \mathrm{N}$ ); and the third one (near the present $13.5^{\circ}-15.5^{\circ} \mathrm{N}$ ) (Figure 1) extending southwestward from the east sub-basin into the southwest (SW) sub-basin when the spreading finally stopped at $16 \mathrm{Ma}$ [9].

\section{Sampling and Methods}

\subsection{Sampling}

The IODP Expedition 349 drilled two sites (U1433 with 2 holes and U1434 with 1 hole) in the Southwest Sub-Basin of the SCS during January-March 2014 [11]. At site U1433, Hole U1433A was cored using the advanced piston corer (APC) to refusal at 188.3 mbsf (meter below seafloor), Hole U1433B was drilled to $186.1 \mathrm{mbsf}$ and then cored using the rotary core barrel (RCB). At site U1434, Hole U1434A was drilled to 197.0 mbsf and then cored with the rotary core barrel (RCB). MORB, dominantly pillow and massive basalt flows, was recovered from the site U1433 at depths of 796.67-857.48 mbsf (Figure 2). The age was determined as $17.3 \mathrm{Ma}$ using Ar-Ar dating [12]. Pillow basalt interposed with hyaloclastite breccia occurred at a depth of 278.27-308.65 mbsf from the site U1434. Ar-Ar dating indicated an age of $\sim 16.3 \mathrm{Ma}[12]$.

Basaltic samples of both sites were collected from the IODP sample repositories at Kochi core center (Japan), under the guidance of local curators. We obtained 11 samples from Hole U1433B and 6 samples from Hole U1434A (Figure 2). Most samples are visually fresh, and only several samples experienced slightly alteration. All the samples were preserved in polyethylene bags for subsequent analyses. 
Site U1433

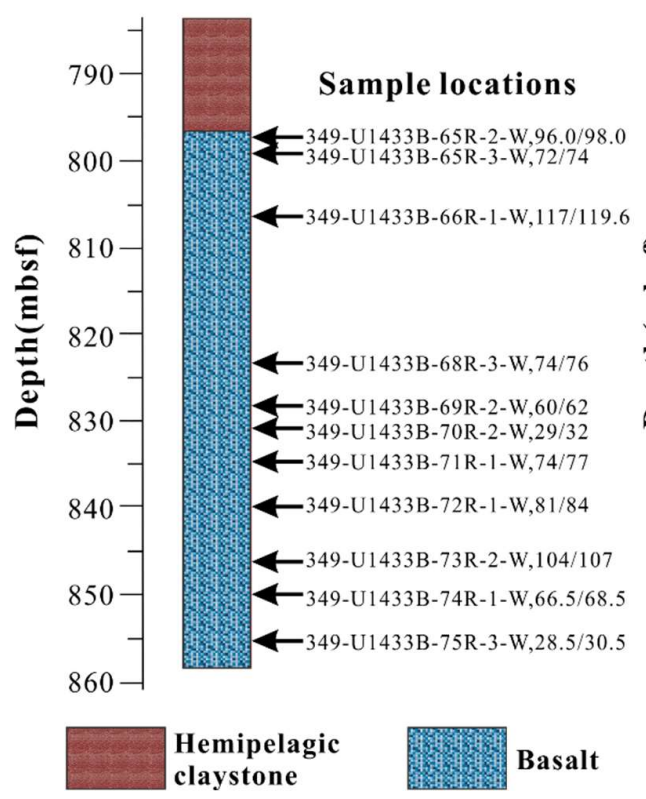

Site U1434

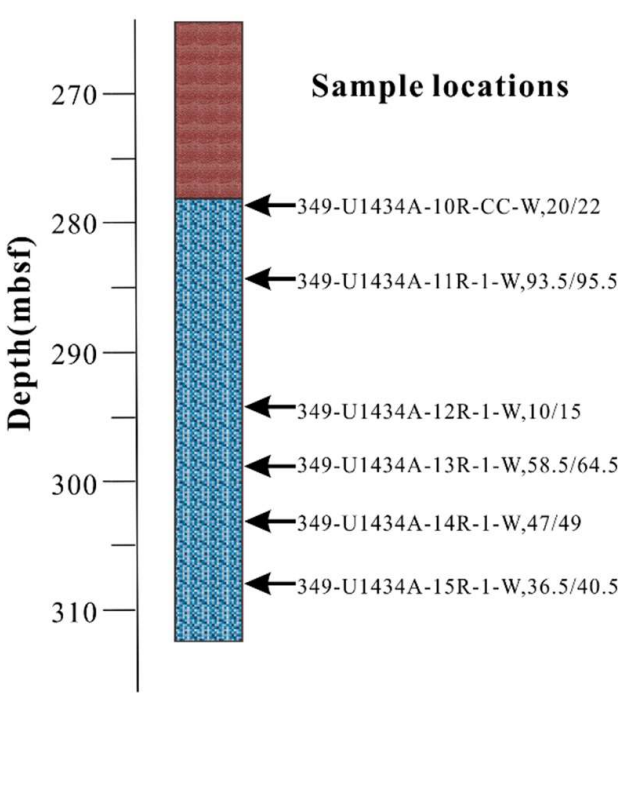

Figure 2. Stratigraphy chart of core samples recovered from the Sites U1433 and U1434. mbsf-meter below seafloor.

\subsection{Analytical Methods}

All the rock samples were one-side polished to make thin sections with a thickness of $0.03 \mathrm{~mm}$. Petrographic and microscopic observation on the thin sections of the SCS basalts were conducted on a Leica DM4500 P LED Polarization Microscope at Ocean College, Zhejiang University.

The major and trace element compositions of the basaltic samples were determined by at the Solid Earth Geochemical Laboratory, Harvard University. The samples were dried and ground to about 200 mesh with an agate mortar. Then, about $\sim 50 \mathrm{mg}$ of each sample was digested in an $\mathrm{HF}: \mathrm{HNO}_{3}$ mixture. The trace elemental concentrations were subsequently analyzed by Thermo's XSeries inductively coupled plasma mass spectrometry (ICP-MS). A matrix $8 \mathrm{~N} \mathrm{HNO}_{3}$ solution with $\mathrm{Ge}(10 \mathrm{ppb})$, In (3 ppb), $\mathrm{Tm}(3 \mathrm{ppb})$, and Bi (3 ppb) was used as the internal standard. The major elemental contents were determined by ICP-MS equipped with a laser ablation system, following the method of Chen and Langmuir [25]. The measurement uncertainty was less than $2 \%$ via tests of blank samples and external standards (BCR-2, BHVO-2, DNC-1, JB-2, W-2a, and VE-32), and duplicate analyses.

The crystal structures of minerals in the samples were determined by $\mathrm{X}$-ray powder diffraction using a PANalytical X'Pert3 Powder XRD at Ocean College, Zhejiang University. The $2 \theta$ ranged from $5^{\circ}$ to $70^{\circ}$ with a step of $0.02^{\circ} \mathrm{min}^{-1}$. The operation voltage and current were maintained at $40 \mathrm{kV}$ and $40 \mathrm{~mA}$, respectively. The crystalline phases were identified from the XRD patterns using MDI Jade (version 6.5) software.

\section{Results}

\subsection{Petrographic and Mineralogical Characteristics}

All samples have a porphyritic texture and the phenocrysts are mainly plagioclase with a grain size of 0.4 to $1.2 \mathrm{~mm}$. Most of them are mostly subhedral with short columns and tabular in shape. The phenocrysts also contain a small number of olivine and most of them are anhedrals with grain sizes of 0.05 to $0.4 \mathrm{~mm}$. Clinopyroxene is rare. The matrix of samples shows intergranular and intersertal texture. It consists mainly of plagioclase and clinopyroxene, most of which are needle-like and slender 
columnar with disordered distribution, and the gap is filled with dark cryptocrystalline (Figure 3a-d). All samples are fresh, and the vesicular structure is not developed.
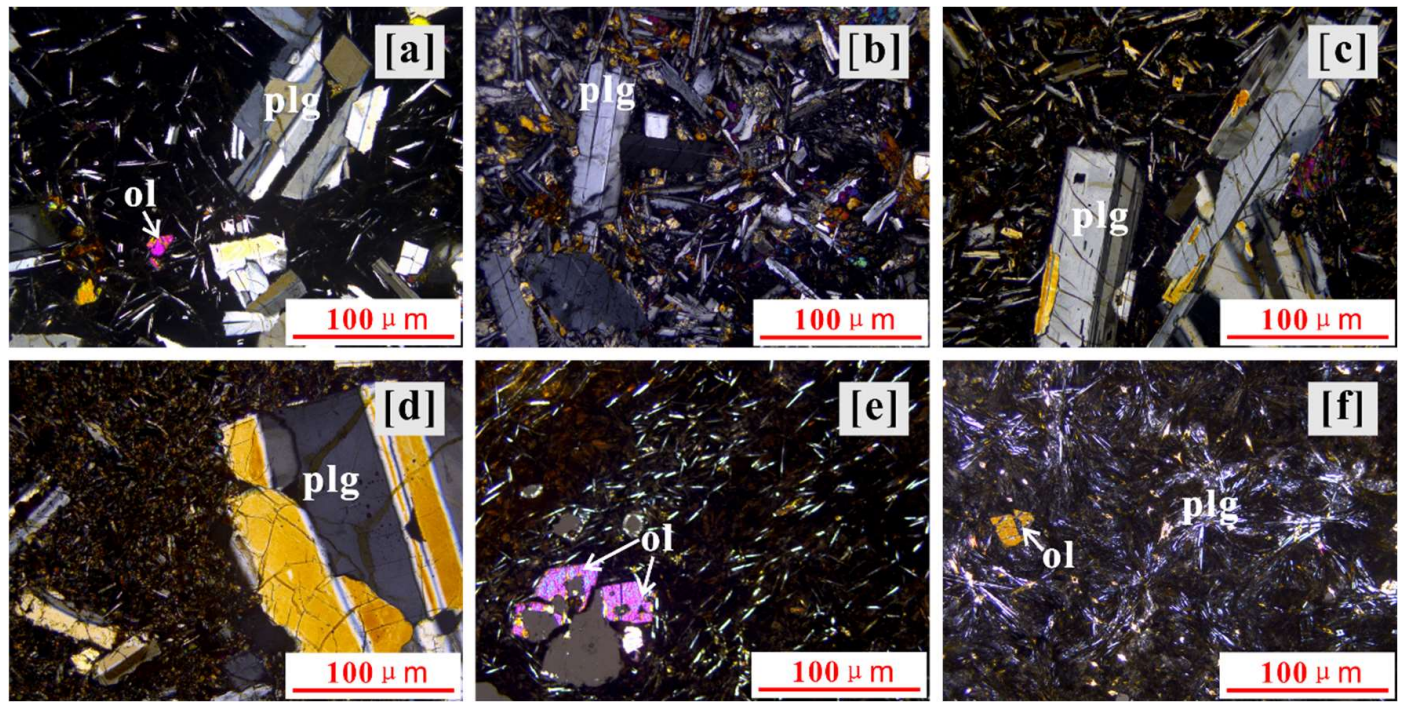

Figure 3. Microscopic observation on the basaltic samples from U1433 and U1434. (a) 349-U1433B-65R2-W,96/98; (b) 349-U1433B-68R-3-W,74/76; (c) 349-U1433B-70R-2-W,29/32; (d) 349-U1433B-72R-1-W,81/84; (e) 349-U1434A-12R-1-W,10/15; (f) 349-U1434A-13R-1-W,58.5/64.5.

XRD patterns are used to determine the minerals of the rock samples [26]. The crystal structures of the basaltic samples are indexed by the XRD patterns (Figure 4). The crystalline minerals are dominated by labradorite, andesine, diopside, and forsterite in the U1433 basalt (Figure 4a,b), and the major minerals of U1434 basaltic samples are andesine, augite, diopside and forsterite (Figure 4c,d).
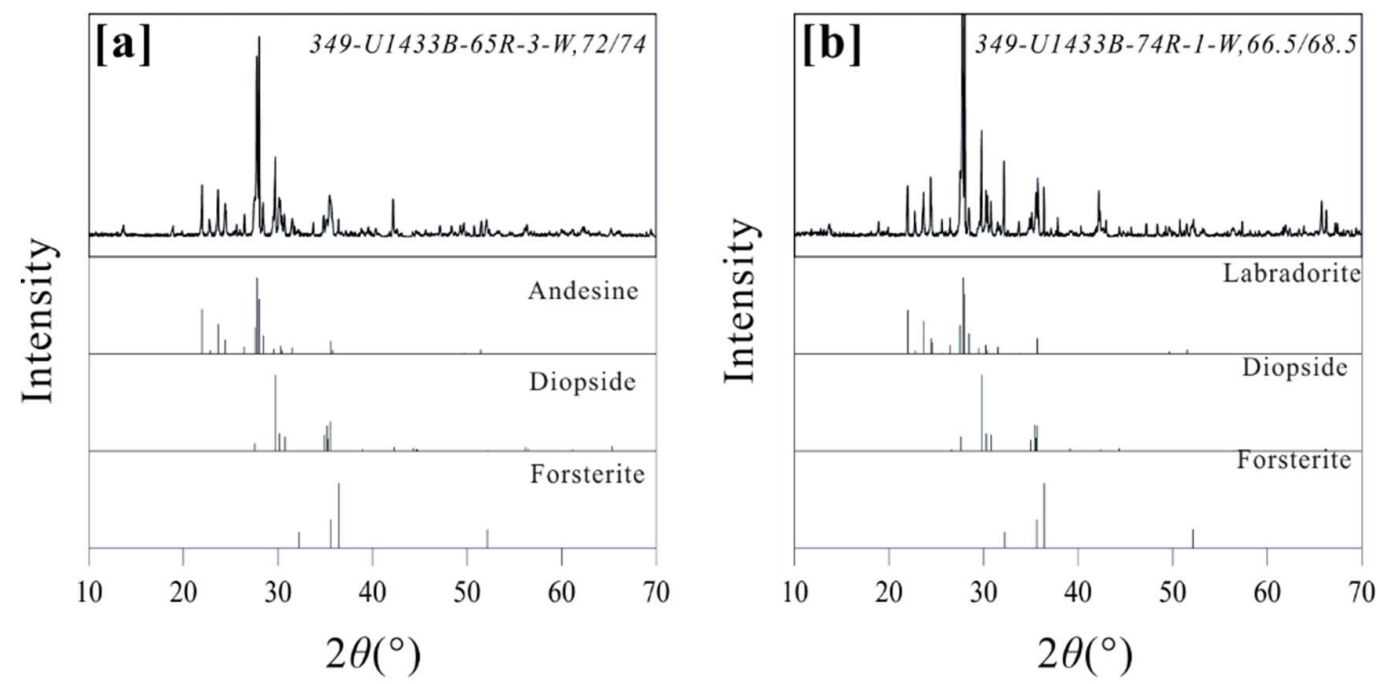

Figure 4. Cont. 

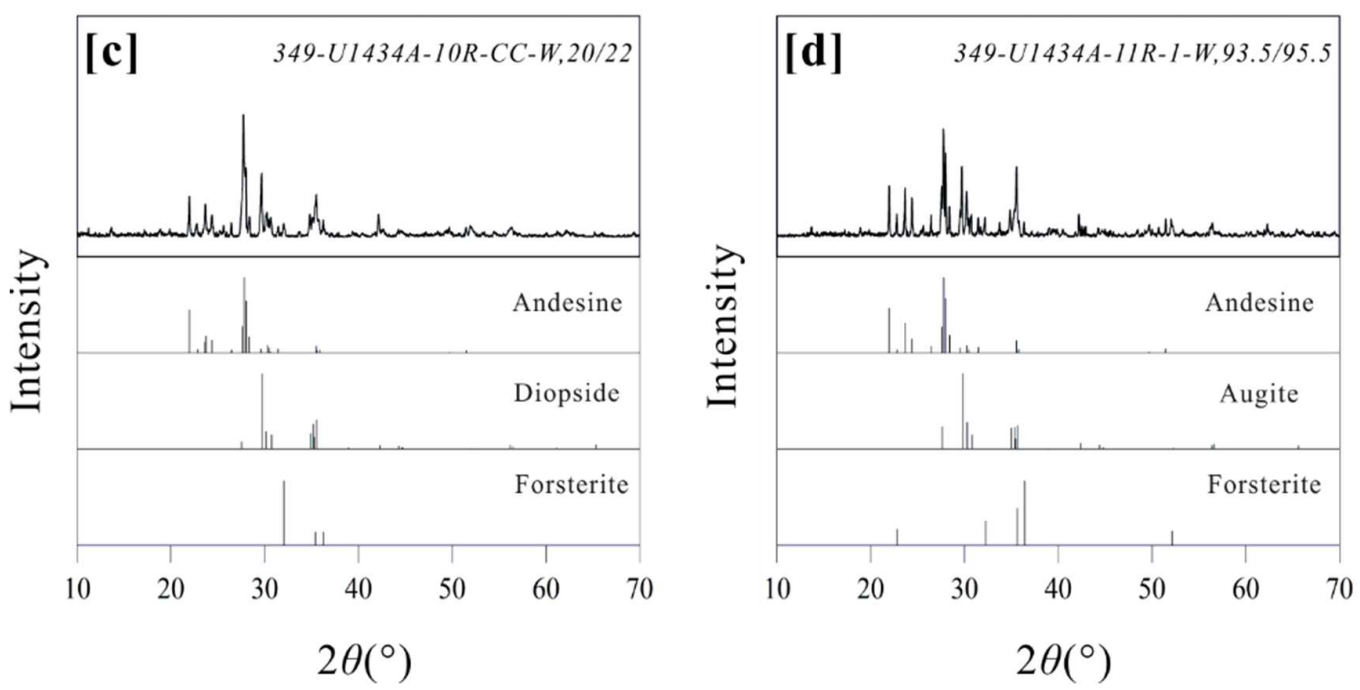

Figure 4. X-ray diffraction patterns of the representative basaltic samples of Sites U1433 and U1434.

(a) 349-U1433B-65R-3-W,72/74; (b) 349-U1433B-74R-1-W,66.5/68.5; (c) 349-U1434A-10R-CC-W,20/22;

(d) 349-U1434A-11R-1-W,93.5-95.5.

\subsection{Major Elements}

The $\mathrm{SiO}_{2}$ contents of $\mathrm{U} 1433$ basalt fall in the range of $48.29 \%$ to $52.09 \%$ with an average value of $50.17 \%$. The U1434 basalt exhibits slightly higher $\mathrm{SiO}_{2}$ concentrations of $49.46 \%-52.10 \%$ (average $51.03 \%$ ). The MgO contents of U1433 and U1434 basalts are 5.03\%-7.65\% and 5.14\%-7.20\%, respectively. The samples from both the site $\mathrm{U} 1433$ and $\mathrm{U} 1434$ exhibit relatively high $\mathrm{CaO}$ and $\mathrm{Al}_{2} \mathrm{O}_{3}$ contents, with values of $10.13 \%-12.46 \%$ and $14.12 \%-18.80 \%$, respectively. According to the major and trace elemental concentrations of basaltic samples, the samples are classified as basalt and basaltic andesite (Figure 5a), belong to the sub-alkaline series. Based on the $\mathrm{K}_{2} \mathrm{O}-\mathrm{SiO}_{2}$ diagram (Figure $5 \mathrm{~b}$ ), all the samples of Site U1433 can be further determined as low-K tholeiitic series, while the bulk of the samples of Site U1434 plot in the fields of the low-K tholeiitic rock series, and a small number plot within the field for the calc-alkaline series.
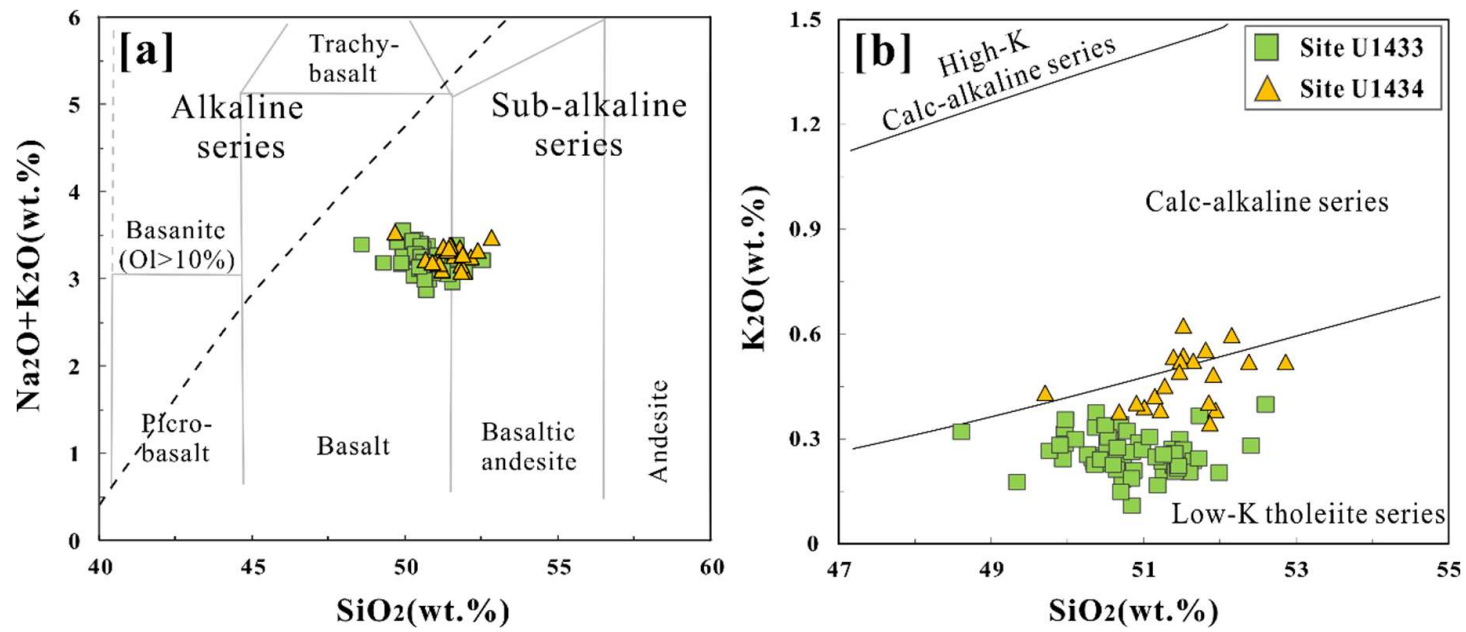

Figure 5. Classification diagrams of (a) total alkalis $\left(\mathrm{Na}_{2} \mathrm{O}+\mathrm{K}_{2} \mathrm{O}\right)$ vs. $\mathrm{SiO}_{2}(\mathrm{TAS})$ and $(\mathbf{b})$ magma series diagrams of $\mathrm{K}_{2} \mathrm{O}$ versus $\mathrm{SiO}_{2}$ for U1433 and U1434 basaltic samples. 


\subsection{Trace Elements}

The trace elemental compositions of basaltic samples from U1433 and U1434 are summarized in Table 1. The primitive mantle-normalized trace-element distribution pattern (Figure 6) is generally similar to that of E-MORB. Several samples presented positive anomalies of $U$ and Sr. The content of compatible elements $\mathrm{Ni}, \mathrm{Cr}$, and Co of the basalts at site U1433 are 70.90-181.29 ppm, 178.70-410.38 ppm, and 32.88-49.41 ppm, respectively. Those of basalts from Site U1434 are 106.22-142.84, 238.80-317.39, and 34.12-48.57 ppm, respectively. The ratios of incompatible elements $(\mathrm{Sr} / \mathrm{Ba})$ of basaltic samples are 3.02-8.43 for Site U1433, and are 2.13-4.01 for Site U1434. The U1434 basalts exhibit higher contents of incompatible elements (more enriched in incompatible elements) than the U1433 samples. For example, the $\mathrm{Zr}$ contents of U1434 basalts are 105.88-125.04 ppm, about 20\%-30\% larger than of the U1433 samples (77.89-117.23 ppm). The contents of $\mathrm{Zr}, \mathrm{Hf}$, and $\mathrm{Nb}$ at both sites are comparable to those of E-MORB $(73,2.03$, and $8.30 \mathrm{ppm})$, but significantly different than those of oceanic island basalt and island-arc basalt [27]. Based on the $\mathrm{La} / \mathrm{Nb}$ ratios, oceanic basalts can be divided into N-MORB with $\mathrm{La} / \mathrm{Nb}>1.0$, E-MORB with $\mathrm{La} / \mathrm{Nb}<1.0$, and HIMU Oceanic Island Basalt (OIB) with $\mathrm{La} / \mathrm{Nb}$ of between 0.6 and 0.7 [27]. The La/ $\mathrm{Nb}$ ratios of basaltic samples of U1433 and U1434 range from 0.73 to 1.01 (average 0.82 ) and from 0.71 to 0.86 (average 0.78 ), respectively. Combined with the primitive mantle-normalized trace-element distribution patterns, it is suggested that both the U1433 and U1434 basalts belong to E-MORB.

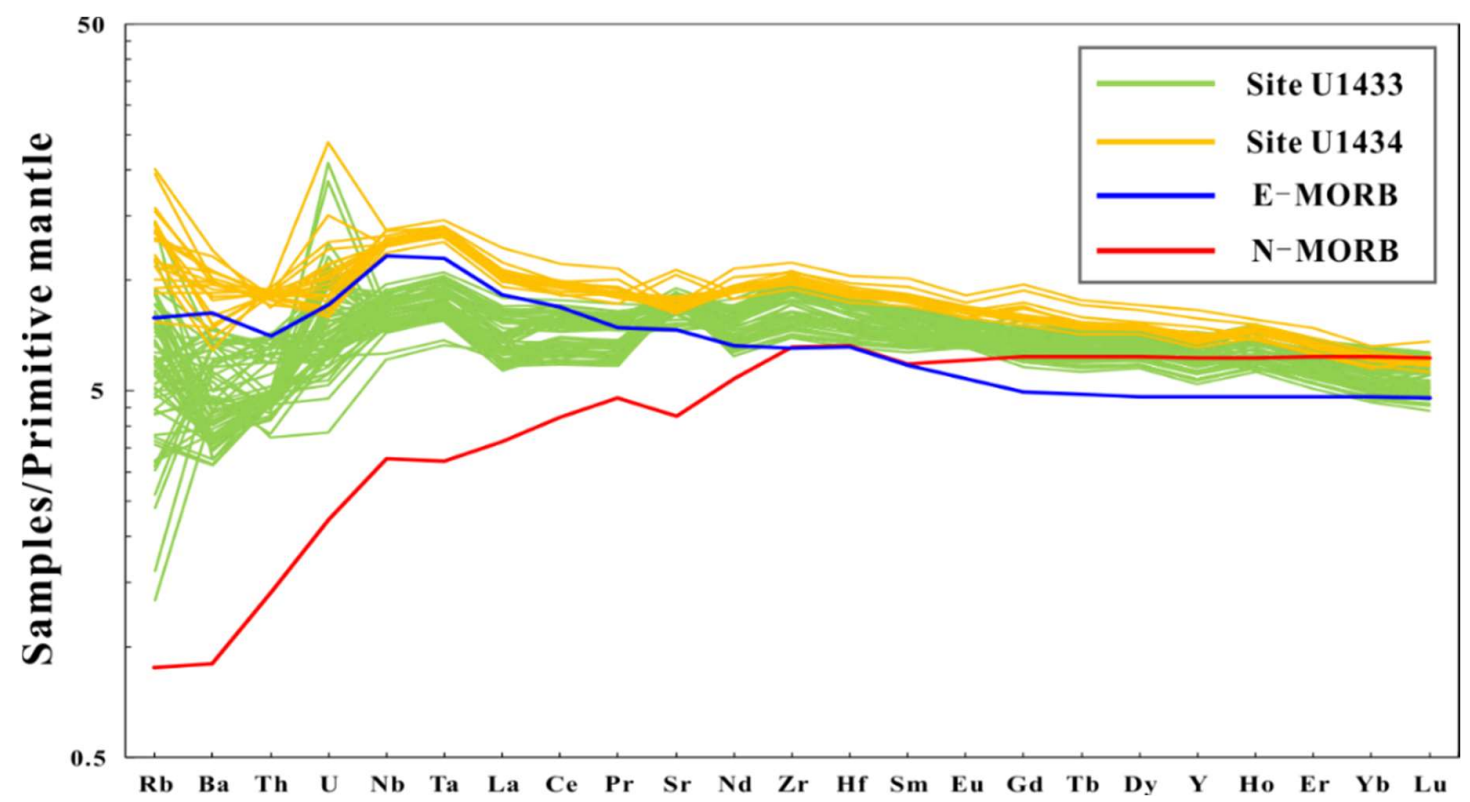

Figure 6. Primitive mantle-normalized spider grams for basaltic samples from Sites U1433 and U1434.

The $\Sigma$ REE values are 42.72-60.21 ppm for site U1433 and 60.44-73.46 ppm for site U1434, respectively. The LREE/HREE and $(\mathrm{La} / \mathrm{Yb})_{\mathrm{N}}$ ratios of U1433 basalt are 1.93-2.18 and 1.01-1.48, respectively, indicating the high degree of fractionation between HREE and LREE. The U1434 samples show slightly higher LREE/HREE (2.28-2.42) and $(\mathrm{La} / \mathrm{Yb})_{\mathrm{N}}(1.59-1.85)$. The $(\mathrm{La} / \mathrm{Sm})_{\mathrm{N}}(0.82-1.21)$ and $(\mathrm{Gd} / \mathrm{Yb})_{\mathrm{N}}$ ratios (1.09-1.48) for samples from both sites, on the contrary, indicate a low degree of fractionation within HREEs and LREEs. The chondrite-normalized REEs distribution patterns (Figure 5b) assemble to the typical REE distribution pattern of E-MORB. No significant Eu and Ce anomalies occurred to the REEs of the SCS basalt, indicating by the $\delta$ Eu values of $0.91-1.07$ and $\delta \mathrm{Ce}$ values of $0.93-1.12$. 
Table 1. Major (wt.\%) and trace element (ppm) concentrations of basaltic samples at Sites U1433 and U1434.

\begin{tabular}{|c|c|c|c|c|c|c|c|c|c|c|c|c|c|c|c|c|c|}
\hline \multirow[t]{2}{*}{ Site } & \multicolumn{11}{|c|}{ U1433 } & \multicolumn{6}{|c|}{ U1434 } \\
\hline & 349-U14 & 349-U14 & 349-U14 & 349-U14 & 349-U14 & 349-U14 & 349-U14 & 349-U14 & 349-U14 & 349-U14 & 349-U14 & 349-U14 & 349-U14 & 349-U14 & 349-U14 & 349-U14 & 349-U14 \\
\hline Sample & 33B-65R & $33 \mathrm{~B}-65 \mathrm{R}$ & $33 \mathrm{~B}-66 \mathrm{R}$ & $33 \mathrm{~B}-68 \mathrm{R}$ & $33 \mathrm{~B}-69 \mathrm{R}$ & 33B-70R & 33B-71R & $33 \mathrm{~B}-72 \mathrm{R}$ & 33B-73R & 33B-74R & 33B-75R & 34A-10R & $34 \mathrm{~A}-11 \mathrm{R}$ & $34 \mathrm{~A}-12 \mathrm{R}$ & $34 \mathrm{~A}-13 \mathrm{R}$ & $34 \mathrm{~A}-14 \mathrm{R}$ & $34 \mathrm{~A}-15 \mathrm{R}$ \\
\hline No. & $\begin{array}{c}-2-\mathrm{W} \\
96.0 / 98.0\end{array}$ & $\begin{array}{l}-3-W \\
72 / 74\end{array}$ & $\begin{array}{c}-1-\mathrm{W}, 117 \\
/ 119.6\end{array}$ & $\begin{array}{l}-3-W \\
74 / 76\end{array}$ & $\begin{array}{l}-2-W \\
60 / 62\end{array}$ & $\begin{array}{l}-2-W \\
29 / 32\end{array}$ & $\begin{array}{l}-1-W \\
74 / 77\end{array}$ & $\begin{array}{l}-1-W \\
81 / 84\end{array}$ & $\begin{array}{c}-2-\mathrm{W} \\
104 / 107\end{array}$ & $\begin{array}{c}-1-W \\
66.5 / 68.5\end{array}$ & $\begin{array}{c}-3-\mathrm{W} \\
28.5 / 30.5\end{array}$ & $\begin{array}{c}\text {-CC-W, } \\
20 / 22\end{array}$ & $\begin{array}{c}-1-\mathrm{W} \\
93.5 / 95.5\end{array}$ & $\begin{array}{l}-1-W \\
10 / 15\end{array}$ & $\begin{array}{c}-1-W \\
58.5 / 64.5\end{array}$ & $\begin{array}{l}-1-W \\
47 / 49\end{array}$ & $\begin{array}{c}-1-\mathrm{W} \\
36.5 / 40.5\end{array}$ \\
\hline $\begin{array}{c}\text { Top } \\
\text { (Dep/m) }\end{array}$ & 797.96 & 799.72 & 807.17 & 823.74 & 827.60 & 831.29 & 835.74 & 840.81 & 846.04 & 850.67 & 856.29 & 278.20 & 284.94 & 294.10 & 298.59 & 303.47 & 308.37 \\
\hline $\begin{array}{c}\text { Bottom } \\
\text { (Dep/m) }\end{array}$ & 797.98 & 799.74 & 807.20 & 823.76 & 827.62 & 831.32 & 835.77 & 840.84 & 846.07 & 850.69 & 856.31 & 278.22 & 284.96 & 294.15 & 298.65 & 303.49 & 308.41 \\
\hline $\mathrm{SiO}_{2}$ & 50.13 & 49.68 & 49.10 & 50.32 & 50.43 & 51.46 & 50.12 & 50.53 & 50.46 & 50.45 & 50.08 & 50.98 & 51.27 & 50.42 & 49.46 & 50.74 & 51.26 \\
\hline $\mathrm{TiO}_{2}$ & 1.479 & 1.493 & 1.489 & 1.379 & 1.386 & 1.541 & 1.317 & 1.281 & 1.675 & 1.160 & 1.516 & 1.632 & 1.636 & 1.754 & 1.779 & 1.711 & 1.643 \\
\hline $\mathrm{Al}_{2} \mathrm{O}_{3}$ & 17.07 & 17.43 & 17.39 & 17.07 & 16.73 & 15.19 & 17.25 & 17.98 & 14.12 & 18.80 & 17.44 & 15.35 & 15.15 & 16.30 & 16.58 & 15.65 & 15.03 \\
\hline $\mathrm{TFeO}$ & 9.37 & 9.82 & 9.33 & 9.07 & 9.29 & 9.25 & 9.53 & 7.86 & 10.43 & 7.98 & 8.68 & 10.42 & 9.99 & 10.09 & 10.78 & 10.21 & 10.04 \\
\hline $\mathrm{MnO}$ & 0.171 & 0.203 & 0.143 & 0.160 & 0.189 & 0.165 & 0.176 & 0.183 & 0.161 & 0.140 & 0.135 & 0.175 & 0.162 & 0.151 & 0.152 & 0.172 & 0.160 \\
\hline $\mathrm{MgO}$ & 6.48 & 5.98 & 7.61 & 6.01 & 6.71 & 6.64 & 5.63 & 5.73 & 7.65 & 5.77 & 6.38 & 6.98 & 7.20 & 5.86 & 5.14 & 6.63 & 7.02 \\
\hline $\mathrm{CaO}$ & 11.21 & 11.54 & 11.15 & 12.11 & 11.40 & 11.68 & 11.97 & 12.46 & 11.95 & 11.81 & 12.09 & 10.68 & 10.55 & 11.48 & 11.71 & 10.97 & 10.77 \\
\hline $\mathrm{Na}_{2} \mathrm{O}$ & 3.06 & 2.92 & 3.00 & 2.95 & 2.85 & 3.02 & 3.13 & 3.04 & 2.63 & 3.04 & 2.78 & 2.71 & 2.80 & 2.84 & 3.10 & 2.79 & 2.76 \\
\hline $\mathrm{K}_{2} \mathrm{O}$ & 0.38 & 0.24 & 0.18 & 0.27 & 0.34 & 0.36 & 0.25 & 0.32 & 0.23 & 0.18 & 0.23 & 0.38 & 0.54 & 0.38 & 0.43 & 0.39 & 0.62 \\
\hline $\mathrm{P}_{2} \mathrm{O}_{5}$ & 0.17 & 0.18 & 0.13 & 0.15 & 0.15 & 0.17 & 0.14 & 0.13 & 0.16 & 0.12 & 0.14 & 0.22 & 0.19 & 0.22 & 0.36 & 0.21 & 0.19 \\
\hline Sum & 99.52 & 99.49 & 99.52 & 99.49 & 99.47 & 99.47 & 99.50 & 99.50 & 99.47 & 99.46 & 99.48 & 99.52 & 99.50 & 99.49 & 99.50 & 99.48 & 99.49 \\
\hline $\mathrm{La}$ & 5.507 & 5.284 & 4.390 & 4.429 & 4.647 & 5.333 & 5.073 & 4.701 & 5.351 & 5.392 & 5.374 & 6.957 & 6.883 & 7.656 & 8.412 & 7.345 & 6.844 \\
\hline $\mathrm{Ce}$ & 13.918 & 13.778 & 11.215 & 10.797 & 11.324 & 12.974 & 12.866 & 11.868 & 13.145 & 13.559 & 13.368 & 16.167 & 16.509 & 17.589 & 19.775 & 17.379 & 16.169 \\
\hline $\mathrm{Pr}$ & 2.267 & 2.243 & 1.864 & 1.779 & 1.866 & 2.067 & 2.028 & 1.881 & 2.059 & 2.148 & 2.135 & 2.538 & 2.569 & 2.783 & 2.962 & 2.647 & 2.528 \\
\hline $\mathrm{Nd}$ & 11.437 & 11.471 & 9.461 & 9.201 & 9.651 & 10.233 & 10.354 & 9.335 & 10.285 & 10.791 & 10.513 & 12.711 & 12.692 & 13.817 & 14.628 & 13.097 & 12.619 \\
\hline $\mathrm{Sm}$ & 3.565 & 3.574 & 2.981 & 3.029 & 3.166 & 3.266 & 3.411 & 2.959 & 3.214 & 3.312 & 3.281 & 3.904 & 3.941 & 4.278 & 4.483 & 4.078 & 3.860 \\
\hline $\mathrm{Eu}$ & 1.251 & 1.235 & 1.096 & 1.116 & 1.142 & 1.123 & 1.187 & 1.098 & 1.128 & 1.141 & 1.148 & 1.338 & 1.369 & 1.464 & 1.530 & 1.387 & 1.325 \\
\hline $\mathrm{Gd}$ & 4.750 & 4.631 & 3.956 & 4.054 & 4.168 & 4.402 & 4.528 & 3.947 & 4.183 & 4.372 & 4.258 & 5.011 & 5.074 & 5.586 & 5.814 & 5.183 & 4.974 \\
\hline $\mathrm{Tb}$ & 0.803 & 0.782 & 0.685 & 0.706 & 0.712 & 0.761 & 0.759 & 0.667 & 0.720 & 0.726 & 0.699 & 0.822 & 0.814 & 0.922 & 0.953 & 0.857 & 0.829 \\
\hline Dy & 5.344 & 5.197 & 4.451 & 4.527 & 4.763 & 5.053 & 5.074 & 4.567 & 4.647 & 4.934 & 4.762 & 5.509 & 5.479 & 6.138 & 6.306 & 5.681 & 5.495 \\
\hline Ho & 1.133 & 1.085 & 0.933 & 0.937 & 0.987 & 1.054 & 1.052 & 0.951 & 0.969 & 1.031 & 0.990 & 1.131 & 1.128 & 1.242 & 1.287 & 1.159 & 1.139 \\
\hline Er & 3.109 & 3.001 & 2.691 & 2.645 & 2.673 & 2.985 & 2.883 & 2.599 & 2.757 & 2.825 & 2.719 & 3.051 & 3.024 & 3.356 & 3.552 & 3.179 & 3.016 \\
\hline $\mathrm{Yb}$ & 3.022 & 2.919 & 2.654 & 2.517 & 2.551 & 2.803 & 2.790 & 2.558 & 2.751 & 2.746 & 2.612 & 2.844 & 2.833 & 3.154 & 3.255 & 2.968 & 2.850 \\
\hline $\mathrm{Lu}$ & 0.464 & 0.459 & 0.397 & 0.377 & 0.389 & 0.436 & 0.421 & 0.407 & 0.409 & 0.426 & 0.417 & 0.454 & 0.447 & 0.454 & 0.504 & 0.460 & 0.449 \\
\hline Y & 33.017 & 31.668 & 27.834 & 27.660 & 28.462 & 31.138 & 30.451 & 27.829 & 28.644 & 29.951 & 29.095 & 32.682 & 32.286 & 35.930 & 37.716 & 34.069 & 32.779 \\
\hline $\mathrm{Zr}$ & 117.226 & 111.758 & 96.892 & 88.110 & 91.743 & 105.145 & 105.145 & 102.612 & 102.135 & 107.664 & 105.006 & 115.902 & 116.203 & 117.994 & 125.045 & 118.944 & 114.376 \\
\hline $\mathrm{Hf}$ & 2.727 & 2.679 & 2.286 & 2.296 & 2.312 & 2.673 & 2.612 & 2.213 & 2.479 & 2.475 & 2.472 & 2.923 & 2.871 & 3.038 & 3.176 & 2.960 & 2.824 \\
\hline
\end{tabular}


Table 1. Cont

\begin{tabular}{|c|c|c|c|c|c|c|c|c|c|c|c|c|c|c|c|c|c|}
\hline \multirow{2}{*}{\begin{tabular}{l|} 
Site \\
$\mathrm{Nb}$
\end{tabular}} & \multicolumn{11}{|c|}{ U1433 } & \multicolumn{6}{|c|}{ U1434 } \\
\hline & 6.353 & 5.920 & 4.339 & 5.264 & 5.517 & 6.408 & 6.354 & 5.752 & 6.512 & 6.742 & 6.669 & 9.309 & 9.725 & 9.456 & 9.807 & 9.697 & 9.012 \\
\hline $\mathrm{Ta}$ & 0.368 & 0.351 & 0.273 & 0.325 & 0.332 & 0.370 & 0.378 & 0.357 & 0.377 & 0.389 & 0.392 & 0.545 & 0.567 & 0.576 & 0.597 & 0.571 & 0.537 \\
\hline $\mathrm{Ba}$ & 34.851 & 32.642 & 36.935 & 32.166 & 45.156 & 50.968 & 42.726 & 46.982 & 52.253 & 46.036 & 48.574 & 69.331 & 81.401 & 51.942 & 45.105 & 68.240 & 84.401 \\
\hline $\mathrm{Cu}$ & 69.785 & 66.938 & 71.366 & 69.617 & 68.731 & 36.047 & 49.701 & 34.971 & 70.201 & 67.064 & 66.732 & 69.251 & 73.472 & 73.123 & 66.154 & 68.353 & 65.050 \\
\hline $\mathrm{Sr}$ & 183.171 & 190.519 & 171.815 & 170.398 & 161.476 & 153.807 & 160.727 & 197.300 & 192.404 & 180.088 & 182.659 & 171.646 & 173.741 & 175.531 & 180.829 & 174.347 & 226.310 \\
\hline $\mathrm{V}$ & 227.182 & 222.186 & 184.532 & 205.979 & 206.998 & 225.843 & 248.687 & 209.871 & 209.149 & 212.311 & 208.182 & 264.171 & 262.410 & 288.806 & 295.666 & 272.737 & 259.730 \\
\hline $\mathrm{Zn}$ & 80.197 & 79.998 & 68.116 & 74.794 & 81.469 & 76.372 & 89.479 & 85.085 & 73.523 & 73.606 & 72.240 & 91.722 & 91.459 & 95.738 & 92.152 & 96.144 & 88.858 \\
\hline $\mathrm{Li}$ & 25.931 & 14.096 & 7.222 & 20.769 & 9.844 & 30.919 & 11.026 & 22.772 & 6.738 & 6.128 & 8.063 & 13.794 & 21.665 & 9.033 & 12.614 & 13.959 & 14.642 \\
\hline $\mathrm{Cr}$ & 334.617 & 334.778 & 366.862 & 369.181 & 410.376 & 257.930 & 300.436 & 321.989 & 274.818 & 246.368 & 266.221 & 249.856 & 268.095 & 308.841 & 287.675 & 317.388 & 295.509 \\
\hline $\mathrm{Ni}$ & 151.460 & 149.100 & 181.292 & 121.733 & 143.017 & 139.380 & 92.436 & 80.518 & 78.832 & 76.186 & 86.010 & 111.288 & 127.348 & 139.329 & 111.571 & 131.808 & 119.342 \\
\hline $\mathrm{Ga}$ & 16.539 & 16.455 & 15.773 & 16.254 & 16.390 & 16.325 & 17.319 & 16.499 & 16.274 & 16.665 & 16.509 & 17.430 & 17.131 & 18.282 & 19.207 & 17.691 & 17.359 \\
\hline $\mathrm{Rb}$ & 7.197 & 2.769 & 3.049 & 5.253 & 3.851 & 6.023 & 4.050 & 5.464 & 3.744 & 1.657 & 3.312 & 6.382 & 8.156 & 4.906 & 6.931 & 6.060 & 12.823 \\
\hline Th & 0.472 & 0.435 & 0.317 & 0.381 & 0.392 & 0.572 & 0.554 & 0.417 & 0.523 & 0.504 & 0.506 & 0.758 & 0.774 & 0.808 & 0.823 & 0.804 & 0.719 \\
\hline $\mathrm{U}$ & 0.145 & 0.112 & 0.081 & 0.139 & 0.183 & 0.142 & 0.211 & 0.132 & 0.123 & 0.135 & 0.130 & 0.175 & 0.189 & 0.266 & 0.500 & 0.192 & 0.231 \\
\hline $\mathrm{Pb}$ & 0.761 & 0.752 & 0.659 & 0.617 & 0.573 & 0.766 & 0.801 & 0.582 & 0.597 & 1.027 & 0.703 & 0.757 & 0.812 & 0.842 & 0.755 & 0.791 & 0.733 \\
\hline
\end{tabular}




\section{Discussion}

\subsection{Seawater Alteration}

In this paper, our purpose was to systematically study the magma formation and evolution processes in the southwest sub-basin of the SCS, and also the possible influence of the Hainan plume on the magmatic activity of the mid-ocean ridge. The fresh basalt samples were necessary. If the samples were not modified by seawater alteration, then they can be used to constrain the mantle properties and deep geodynamic processes [28]. In the primitive mantle-normalized trace-element diagrams (Figure 6), some of the samples in both sites show positive $U$ anomalies. Uranium is a water-soluble element, whereas Th is a water-insoluble element [29], so the interaction of seawater with basalt will cause the altered sample enriched in $U$, but has little effect on Th. When the seawater interacts with the basalt, the Th/U ratio will deviate from the chondrite line. In the Th-U diagram (Figure 7), we also added the unaltered MORB glass data [30]. It shows that the Th/U ratio of most samples at site U1433 and U1434 does not deviate from the chondrite line, and only a few samples deviate from the chondrite line. Those samples also have positive $U$ anomalies in the primitive mantle-normalized trace-element distribution diagram (Figure 6). In addition, no significant Ce anomalies were observed in our samples, which suggests that the effect of subsea weathering on basaltic samples can be negligible [1]; therefore, we excluded that these samples were significantly affected by seawater alteration, and are all fresh. We used them to constrain the magma formation and evolution processes and mantle properties, discussed in the following part.

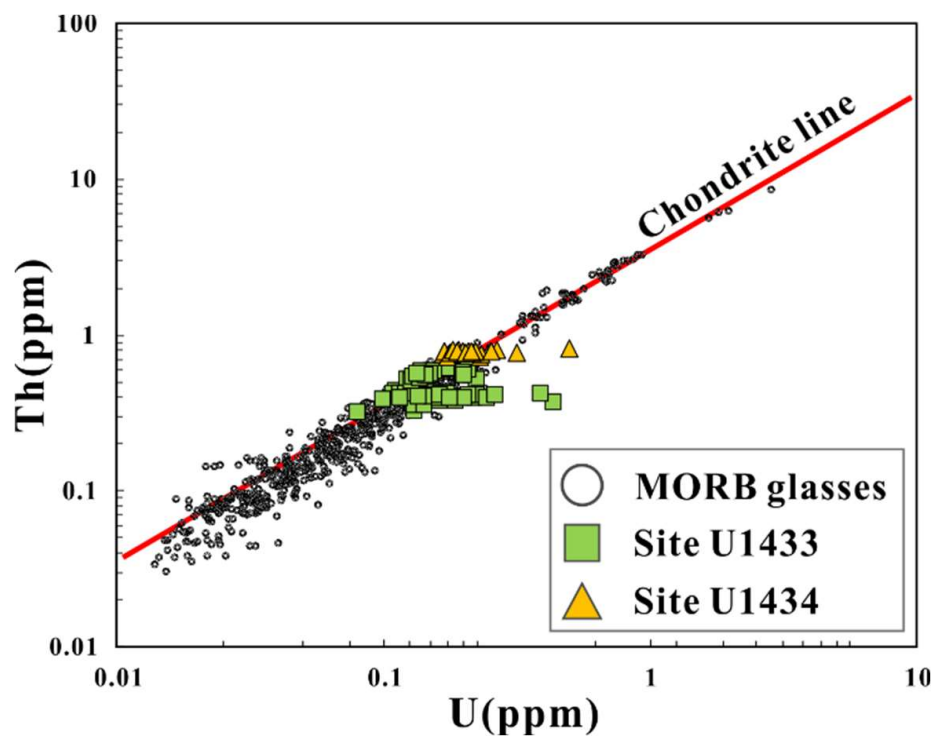

Figure 7. Th-U correlation for basaltic samples at Sites U1433 and U1434. Red line represents the Chondrite line.

\subsection{Fractional Crystallization}

The basaltic primary magma would undergo fractional crystallization under different temperature and pressure conditions during its ascent and migration after its formation, which is an important part of the magma evolution process [31]. The magnesium number $\left(\mathrm{Mg} \#=\left(\mathrm{Mg}^{2+} /\left(\mathrm{Mg}^{2+}+\mathrm{Fe}^{2+}\right)\right)\right)$ can be used to trace the fractional crystallization of mid-ocean ridge basalts [32]. The Mg\# of our samples ranges from 51 to 62 (average 57) and 49 to 59 (average 57), respectively. This suggests that the primitive magma of the mid-ocean ridge basalts at the two sites experienced fractional crystallization during their upward migration [33]. There is a good linear relationship between $\mathrm{MgO}$ and other oxides. For example, $\mathrm{SiO}_{2}, \mathrm{~K}_{2} \mathrm{O}, \mathrm{Ni}$, and $\mathrm{Cr}$ decreased with decreasing $\mathrm{MgO}$, whereas the $\mathrm{CaO}, \mathrm{Al}_{2} \mathrm{O}_{3}, \mathrm{Na}_{2} \mathrm{O}$, $\mathrm{TiO}_{2}, \mathrm{TFeO}$, Sr, and $\mathrm{Y}$ increased; however, the $\mathrm{CaO} / \mathrm{Al}_{2} \mathrm{O}_{3}$ ratios remained unchanged. In Figure 8 , these 
typical variation trend characteristics may be due to the fractional crystallization of olivine, plagioclase, and pyroxene during magma evolution [34]. In this study, no obvious Eu anomalies were observed, indicating that the crystallization of plagioclase is insignificant [33]. The variation between $\mathrm{TFeO}, \mathrm{CaO}$, $\mathrm{CaO} / \mathrm{Al}_{2} \mathrm{O}_{3}$, and $\mathrm{MgO}$ can be explained by the fractional crystallization of pyroxene during magma evolution [34]; however, as shown in Figure 8, the clinopyroxene may not be the main fractional phase. The primary magma of site U1433 and U1434 have mainly undergone the fractional crystallization of olivine, accompanied by the relatively weak fractional crystallization of plagioclase and clinopyroxene.
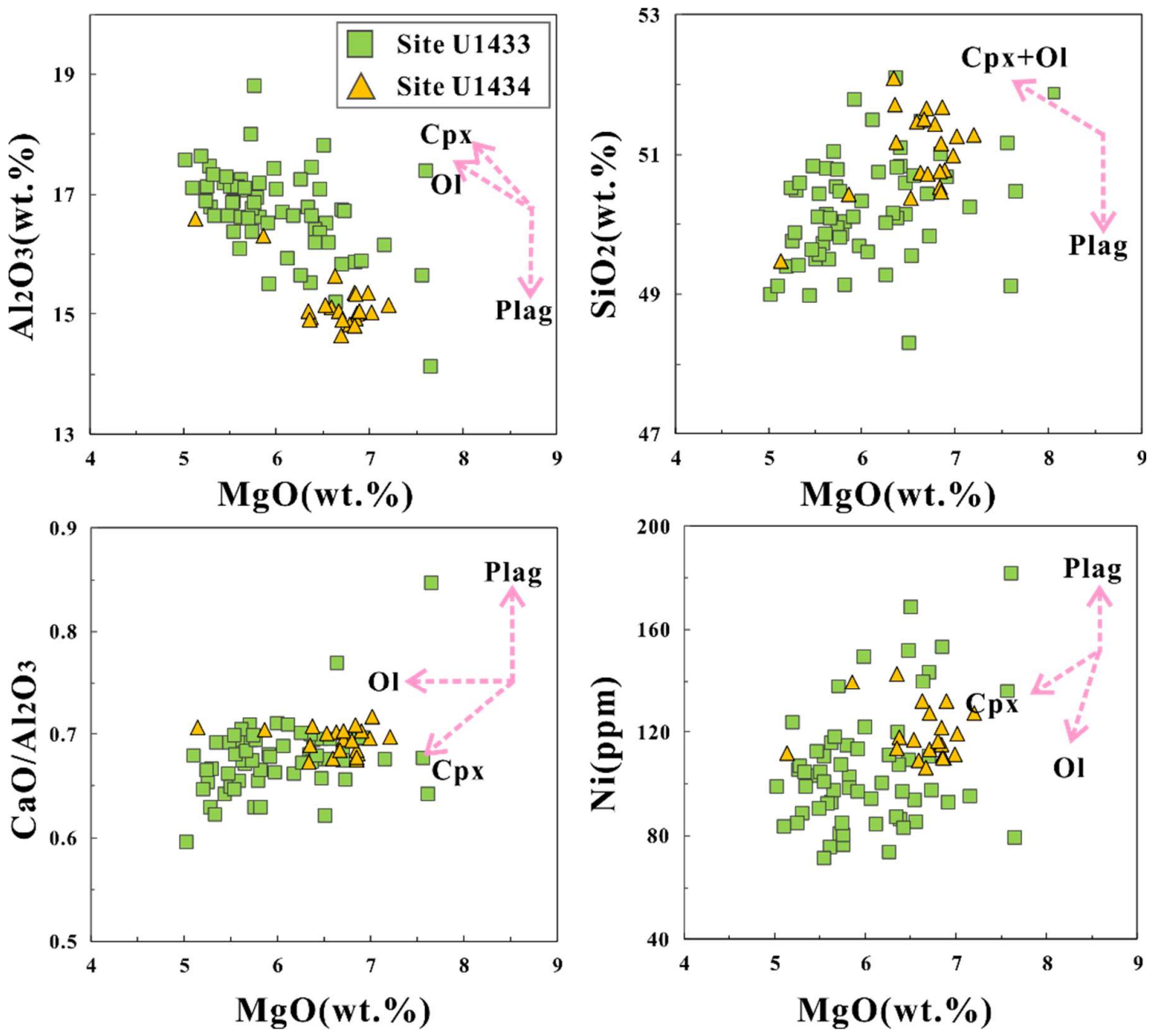

Figure 8. Variation diagrams of $\mathrm{MgO}$ versus selected Major (wt.\%), trace elements (ppm), and element ratios for basaltic samples at Sites U1433 and U1434.

\subsection{Constrain the Source Mantle}

The lherzolites, which make up the mantle, will partially melt under the decompression caused by the expansion of the mid-ocean ridge, thus forming magma $[31,33]$. The types of lherzolites vary with the depth of mantle. In general, the upper mantle, from the shallow to the deep, is the plagioclase peridotite region (the mantle depth $<30 \mathrm{~km}$ ), the spinel peridotite region (the mantle depth $30-80 \mathrm{~km}$ ) and the garnet peridotite region (the mantle depth $>80 \mathrm{~km}$ ) [33]. As is seen in the chondrite normalized $(\mathrm{Tb} / \mathrm{Yb})_{\mathrm{N}}-(\mathrm{La} / \mathrm{Sm})_{\mathrm{N}}$ diagram (Figure $\left.9 \mathrm{a}\right)$, the $(\mathrm{Tb} / \mathrm{Yb})_{\mathrm{N}}$ values of the basaltic samples at the two sites in this study are all less than 1.8, all of which fall within the spinel peridotite region, indicating that the magma melting depth of the two sites is less than $80 \mathrm{~km}$. The $\mathrm{Nb} / \mathrm{Y}-\mathrm{SiO}_{2}$ diagram can be used to study the melting conditions of the magma source of the mid-ocean ridge basalt [35]. In Figure 9b, all samples plot into the low-pressure and highly partially melted tholeiitic magma area, indicating 
that the magma of the two sites is formed by high partial melting. Thus, the basaltic magmas at site U1433 and U1434 in the southwest sub-basin of the SCS might be mainly formed by low-pressure partial melting of spinel lherzolite, with the majority of melting occurred shallower than the garnet stability field.
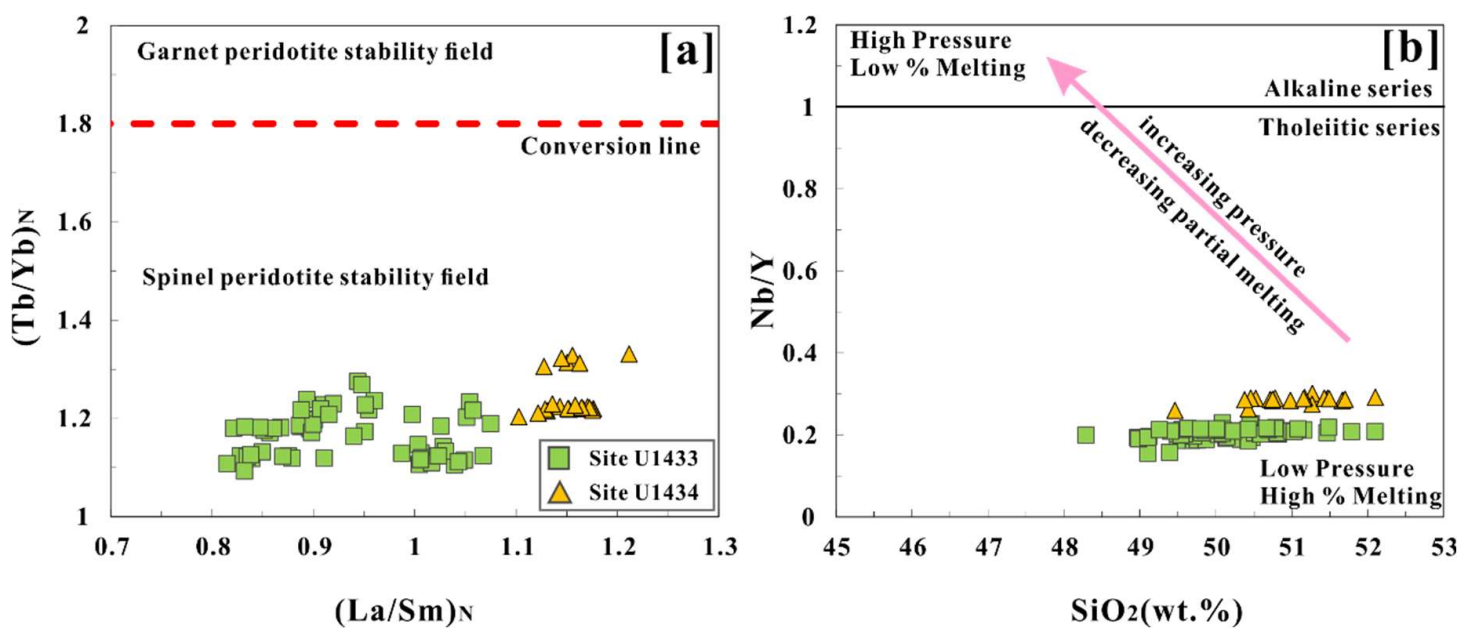

Figure 9. Diagrams of $(\mathrm{Tb} / \mathrm{Yb})_{\mathrm{N}}$ versus $(\mathrm{La} / \mathrm{Sm})_{\mathrm{N}}$ : (a) (after ref. [36]) and $\mathrm{Nb} / \mathrm{Y}$ versus $\mathrm{SiO}_{2}$; (b) (after ref. [35]) for basaltic samples at Sites U1433 and U1434. Red dashed line in (a) represents the conversion line, and it corresponds to a depth of $80 \mathrm{~km}$.

\subsection{Mantle Melting}

Basaltic magma is formed by the partial melting of mantle lherzolite, and the mantle melting has a significant effect on the geochemical composition of basalt [31]. Previous studies have shown that the change range of compatible elements concentration is small, whereas the ratios of strong incompatible elements to weak incompatible elements will increase with the increase of the partial melting degree [37]. With the crystallization degree increasing, the concentration of compatible elements in the melt will decrease sharply; whereas those of incompatible elements increased, and the increase is not related to the incompatibility of the elements, thus the ratios of the strong incompatible elements/weak incompatible elements does not change significantly [37]. The compatible elements (Ni, Cr, and Co) concentration of site U1433 samples vary greatly, and the ratio of incompatible elements ( $\mathrm{Sr} / \mathrm{Ba})$ varies indistinctively, which means those samples are related by fractional crystallization, but also influenced by different degree of partial melting. The compatible elements concentration of Site U1434 samples varies greatly, whereas the ratio of incompatible elements remain almost constant, which reflects the magma of Site U1434 is formed by fractional crystallization. In addition, the characteristic parameter values of rare earth elements can also be used to constrain the genesis process of rock [33]. According to the La/Sm-La diagram, it can be used to discriminated whether the magma is formed by partial melting or fractional crystallization. During partial melting, the La/Sm and La of the melt increased, whereas, in the process of fractional crystallization, the La/Sm remains constant, but La increased [33]. Figure 10a shows a non-significant positive correlation for most Site U1433 samples, and near-horizontal distribution trend for Site U1434 samples, also a non-significant positive correlation between two sites. The results mean that the diversity of U1433 basalt components is due to fractional crystallization and difference partial melting degree, and those of Site U1434 is due to fractional crystallization only. Combining with the $\Sigma$ REE-MgO diagram (Figure 10b), the $\Sigma$ REE value of different sites shows a significant difference, that is, the $\Sigma$ REE value of site U1434 samples is generally higher than site U1433, suggesting partial melting may be the dominate process during the magma evolution of our basalts, and there is a difference in melt fraction between the two sites. 

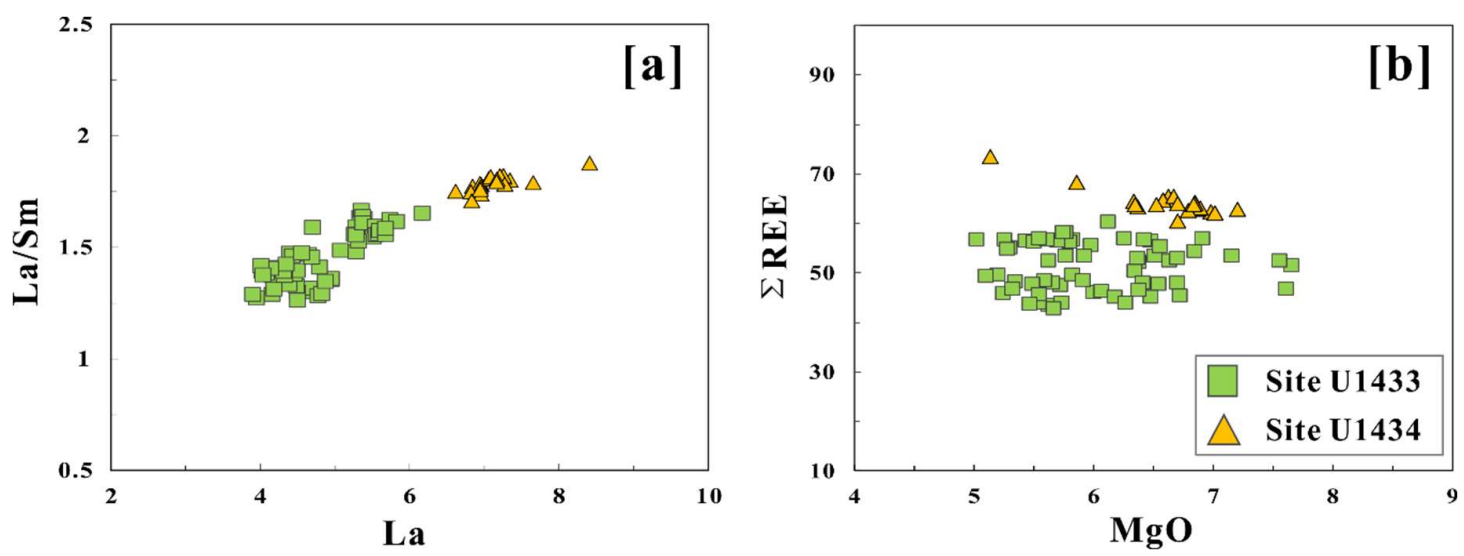

Figure 10. Diagrams of $\mathrm{La} / \mathrm{Sm}$ versus $\mathrm{La}(\mathbf{a})$ and $\Sigma \mathrm{REE}$ versus $\mathrm{MgO}$ (b) for basaltic samples at Sites U1433 and U1434.

In order to clarify the difference in melt fraction between two sites, we quantitatively calculated the partial melting degree (F) of magma. By summarizing the experimental results of a large number of MORBs, Niu and Batiza [38] obtained an empirical formula to correct the sample composition:

$$
\text { Oxide }_{(8)}=\text { Oxide }_{(\text {data })}+\Sigma m_{n}\left(8^{n}-\mathrm{MgO}^{n}\right),
$$

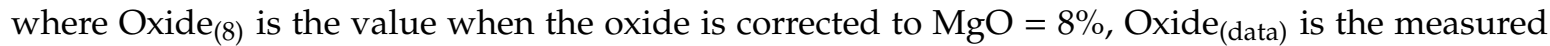
content value of the oxide (except $\mathrm{MgO}$ ), $m_{n}$ is the empirical coefficient, $n$ is the regression number. The empirical coefficients were corrected by Niu et al. [39] (Table 2). The data of this empirical formula are all from MORBs, and it has a good effect on the study of MORBs [31]. According to the relationship among $\mathrm{Na} 8, \mathrm{Ca} 8$, and $\mathrm{Al} 8$, Niu and Batiza [38] put forward an empirical formula for quantitative calculation of partial melting degree $(F)$ :

$$
F(\text { wt. })=19.202-5.175 \times \mathrm{Na} 8+15.537 \times \mathrm{Ca} 8 / \mathrm{Al} 8 .
$$

Table 2. Empirical parameters when basalt composition is corrected to $\mathrm{MgO}=8 \%$.

\begin{tabular}{ccccc}
\hline Oxides & $\mathbf{m} \mathbf{1}$ & $\mathbf{m} \mathbf{2}$ & $\mathbf{m} \mathbf{3}$ & $\mathbf{m} \mathbf{4}$ \\
\hline $\mathrm{SiO}_{2}$ & -9.5261 & 1.2242 & -0.0532 & 0 \\
$\mathrm{TiO}_{2}$ & 6.9928 & -1.5294 & 0.1305 & -0.0039 \\
$\mathrm{Al}_{2} \mathrm{O}_{3}$ & -3.7912 & 0.6477 & -0.0297 & $1.5876 \times 10^{-5}$ \\
$\mathrm{FeO}$ & 14.8703 & -2.9130 & 0.2100 & -0.0049 \\
$\mathrm{CaO}$ & 0.7951 & 0.1405 & -0.0127 & 0 \\
$\mathrm{~K}_{2} \mathrm{O}$ & -0.1817 & 0.0091 & 0 & 0 \\
$\mathrm{Na}_{2} \mathrm{O}$ & -0.8958 & 0.0796 & -0.0029 & 0 \\
$\mathrm{P}_{2} \mathrm{O}_{5}$ & -0.094 & 0.005 & 0 & 0 \\
\hline
\end{tabular}

According to the above formula, the partial melting degree of site U1433 and U1434 is $14.06 \%-19.40 \%$ and $16.35 \%-18.47 \%$, respectively. In general, the partial melting degree of site U1433 is slightly higher than that of Site U1434.

Considering Figure 10 and the Sr-Nd-Pb-Hf isotopes characters of Sites U1433 and U1434 of Zhang et al. [14], we suggest that the geochemical composition of basalts between Sites U1433 and U1434 is mainly controlled by different degrees of partial melting. Research has shown that a spreading ridge would decrease in the degree of melting before the cessation of spreading because of decreasing spreading rate $[40,41]$. The partial melting degree of the magma source area of Site 1434 is lower than 
that of Site U1433; therefore, we proposed that as the ridge ceased in spreading, the mid-ocean ridge of the southwest sub-basin of the SCS has decreased in mantle melting degree.

\subsection{Magmatic Source}

The SCS surrounded by subduction zones is an oceanic basin formed by the splitting of the eastern Eurasian continent, and there may be a Hainan plume beneath Leizhou-Hainan region which might influence the mid-ocean ridge magmatic activity (Figure 1). Given its relatively young age and small size, the magmatic source of the MORBs in the SCS may contain these complex tectonic information. Based on all the discussion above, we suggest that the MORBs at Sites U1433 and U1434 have undergone fractional crystallization and cannot be directly used to constrain the characteristics of the magma source; however, some trace element ratios of basalt can still reflect the material composition characteristics of its source area [42-45]. For example, the average $\mathrm{Nb} / \mathrm{Ta}$ and $\mathrm{Zr} / \mathrm{Hf}$ ratios of Site U1433 are 16.15 and 39.74, respectively, and of site, $\mathrm{U} 1434$ are 16.38 and 39.68, respectively. Those samples are similar to the primitive mantle, whose $\mathrm{Nb} / \mathrm{Ta}$ and $\mathrm{Zr} / \mathrm{Hf}$ values are (17.5 \pm 0.5$)$ and 36.27 [33], respectively. The $\mathrm{Ce} / \mathrm{Pb}$ ratio is an effective tool for studying geochemical properties of basalt source areas [31]. The average $\mathrm{Ce} / \mathrm{Pb}$ ratios of Sites U1433 and U1434 are 18.55 and 21.16, respectively, and are between the $\mathrm{Ce} / \mathrm{Pb}$ values of the continental crust ( 4) and the typical MORB and OIB (25 \pm 5$)$ [45]. The average $\mathrm{Nb} / \mathrm{U}$ ratios of Sites U1433 and U1434 are 37.76 and 43.38, respectively, slightly lower than the $\mathrm{Nb} / \mathrm{U}$ values of MORB and OIB (47 \pm 10$)$, and even some samples are lower than the $\mathrm{Nb} / \mathrm{U}$ values of the primitive mantle $(\sim 30)$. The basaltic samples of the two sites are fresh, and the influence of seawater alteration to $U$ anomalies is insignificant, thus the $\mathrm{Nb} / \mathrm{U}$ values characteristics can suggest that the source area may contain enriched components (may be crust material) [43,44].

Basalt $\mathrm{Nb} / \mathrm{Th}$ and $\mathrm{Ta} / \mathrm{U}$ values can be used to reveal the origin of the mantle, and this is because the $\mathrm{Nb} / \mathrm{Th}$ and $\mathrm{Ta} / \mathrm{U}$ ratios were not sensitive to fractional crystallization, whereas the relatively water-soluble $T h$ and $U$ in the descending oceanic lithosphere are carried away by a series of subduction dehydration, leaving relatively water-insoluble $\mathrm{Nb}$ and $\mathrm{Ta}$ [46]; therefore, when the residual lithosphere is added to the ocean basalt source, it will lead to the enrichment of $\mathrm{Nb}$ and Ta in these basalts, thereby increasing the $\mathrm{Nb} / \mathrm{Th}$ and $\mathrm{Ta} / \mathrm{U}$ values. It can be seen in Figure 11a that the linear correlation between the $\mathrm{Nb} / \mathrm{Th}$ and Th values of Sites U1433 and U1434 samples shows a certain negative correlation. At the same time, the $\mathrm{Nb} / \mathrm{Th}$ values of the two sites samples are higher than those of the primitive mantle, and closer to that of E-MORB, indicating that the magma source composition of the samples is likely to be affected by the enriched components, which is consistent with the conclusion drawn from the study of $\mathrm{Nb} / \mathrm{U}$ values of the two sites. In Figure $11 \mathrm{~b}$, the distribution trend of the sample points of the two sites is relatively closer to the lower continental crust (LCC), suggesting that the enrichment components in magma source of the MORBs at the two sites are probably containing the lower crust. In addition, because the partition coefficients of the four elements $\mathrm{Nb}$, $\mathrm{Th}$, $\mathrm{Ta}$, and $\mathrm{U}$ show the characteristics of $\mathrm{D}_{\mathrm{Nb}} \approx \mathrm{D}_{\mathrm{Th}}<\mathrm{D}_{\mathrm{Ta}} \approx \mathrm{D}_{\mathrm{U}}$, when the residual lithosphere is added to the oceanic basalt source, it will lead to excess $\mathrm{Nb}^{*}$ and $\mathrm{Ta}^{*}$, so the $\mathrm{Nb}^{*}$ and $\mathrm{Ta}^{*}$ values of basalts can also be used to reveal the magma source characteristics of basalts [43]. The values of $\mathrm{Nb}^{*}$ and $\mathrm{Ta}^{*}$ of samples at Site U1433 range from 1.21 to 1.96 (average 1.56) and from 0.45 to 1.73 (average 1.20), respectively, and the values of $\mathrm{Nb}^{*}$ and $\mathrm{Ta}^{*}$ of samples at Site U1434 range from 1.36 to 1.50 (average 1.40) and from 0.61 to 1.67 (average 1.36), respectively. That is to say, the values of $\mathrm{Nb}^{*}$ of all samples at both sites are greater than 1 , and the values of $\mathrm{Ta}^{*}$ of most samples at the two sites are greater than 1 , indicating that the magma source of the mid-ocean ridge basalts at Sites U1433 and U1434 may be influenced by the enriched components of the recycled lithosphere. 

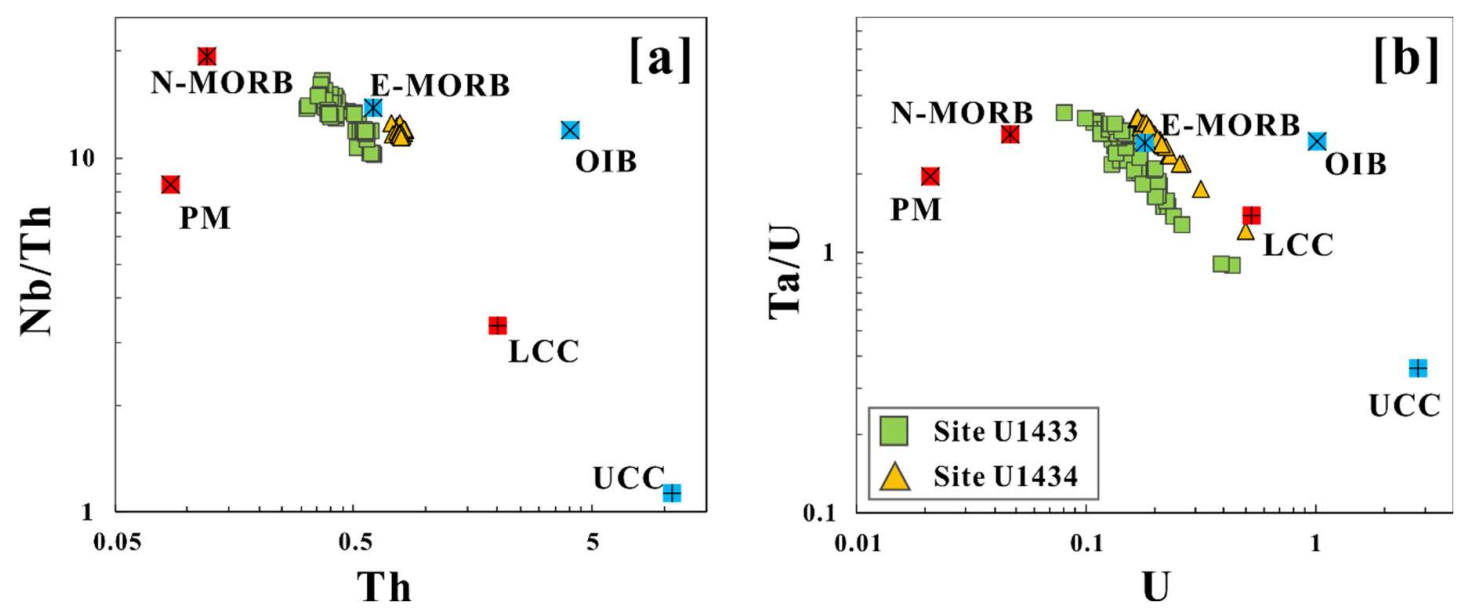

Figure 11. Diagrams of $\mathrm{Nb} / \mathrm{Th}$ versus $\mathrm{Th}(\mathbf{a})$ and $\mathrm{Ta} / \mathrm{U}$ versus $\mathrm{U}$ (b) for basaltic samples at Sites U1433 and U1434. Trace element abundances of the primitive mantle (PM) are from Hofmann [42], trace element abundances of E-MORB, normal mid-ocean ridge basalts (N-MORB), and Oceanic Island Basalt (OIB) are from Sun and McDonough [27], trace element abundances of lower continental crust (LCC) and upper continental crust (UCC) are from McLennan [47].

The magmatic source of both two sites may contain enriched components of the lower crust and/or the recycled lithosphere. It is necessary to distinguish whether these enriched components are due to high-level crustal contamination, and/or a source feature. Zhang et al. [14] simulated the influence of the Hainan mantle plume and the continental lower crust on the composition of the depleted upper mantle, and found that the composition of the mantle in the southwestern sub-basin of the SCS (such as the characteristics of depleted $\mathrm{Pb}$ isotopes) reflects the existence of the continental lower crust mixing in the SCS mantle during the process of SCS seafloor spreading, and propose that the Hainan plume might have not only contaminated the depleted mantle under the South China Sea, but also promoted the effective mixing of the lower continental crust into the asthenosphere; however, the study of Yang et al. [16] shows that the Hainan mantle plume might contain large amounts of recycled oceanic crust components, which are ultimately derived from the Indian and Pacific oceanic subduction. If so, the Hainan plume may take recycled oceanic crust components into the magmatic source of MORBs. Based on the previous research results, we suggest that the enriched components in the magmatic source of southwestern sub-basin during the late period of SCS spreading are the lower continental crust and the recycled oceanic crust. They are probably the result of the lower crust components mixed into the asthenosphere promoted by the Hainan plume during the seafloor spreading of the South China Sea and the recycled oceanic crust components formed by the Indian and Pacific oceanic subduction, respectively.

\section{Conclusions}

This paper studies the geochemical characteristics of the mid-ocean ridge basalts at Sites U1433 and U1434 of the International Ocean Discovery Program (IODP) Expedition 349 in the southwest sub-basin of the SCS, and obtained the following points:

(1) All Site U1433 MORBs and the bulk of Site U1434 MORBs belong to the sub-alkaline low-potassium tholeiitic basalt series. MORBs at IODP Sites U1433 and U1434 are all E-MORB type basalts, but Site U1434 is more enriched with incompatible elements than Site U1433.

(2) MORBs at IODP site U1433 and U1434 are basically unaffected by seawater alteration, and the primary magma of both sites mainly undergone the fractional crystallization of olivine, accompanied by the relatively weak fractional crystallization of plagioclase and clinopyroxene. The different magma evolution between the two sites is mainly controlled by different degrees of 
partial melting at different spreading rates. The degree of melting of Site U1434 is lower than that of Site U1433.

(3) The trace element characteristics of the MORBs at IODP Sites U1433 and U1434 show that the basaltic magmas might be mainly formed by low-pressure and high-level partial melting of spinel lherzolite, with the majority of the melting occurred shallower than the garnet stability field.

(4) MORBs at Sites U1433 and U1434 may involve magma sources containing crust materials, and the magma source of the southwest sub-basin basalts may have been contaminated by lower continental crust and contributed by recycled oceanic crust components during the opening of the SCS.

Author Contributions: Conceptualization, K.S., X.L., and X.-G.C.; methodology, K.S., T.W. and X.-G.C.; software, K.S.; validation, K.S. and X.-G.C.; formal analysis, K.S. and X.L.; investigation, K.S.; resources, C.-F.L. and X.-G.C.; data curation, K.S., T.W. and X.-G.C.; writing-original draft preparation, K.S.; writing-review and editing, K.S. and T.W.; visualization, K.S.; supervision, K.S. and X.-G.C.; project administration, C.-F.L. and X.-G.C.; funding acquisition, C.-F.L. and X.-G.C. All authors have read and agreed to the published version of the manuscript.

Funding: This research was funded by the National Natural Science Foundation of China (No. 41761134051).

Acknowledgments: We would like to express our gratitude to the Solid Earth Geochemical Laboratory, Harvard University for data testing. We are also thankful to Tao Wu and Tiansheng Tao for their helpful suggestions.

Conflicts of Interest: The authors declare no conflict of interest.

\section{References}

1. Ding, X.; Li, J.; Zheng, C.Q.; Huang, W.; Cui, R.Y.; Dou, Y.G.; Sun, Z.L. Chemical composition on the basalts on east pacific rise (1.5 N-1.5 S) and south mid-Atlantic ridge (13.2 S). Mar. Geol. Quat. Geol. 2014, 34, 57-66, (In Chinese with English Abstract).

2. O'Hara, M.J. The bearing of phase equilibria studies in synthetic and natural systems on the origin of basic and ultrabasic rocks. Earth-Sci. Rev. 1968, 4, 69-133.

3. Zhang, S.M.; Wang, F.Z. Basalts action on research geosphere deep-course and structural setting. Adv. Earth Sci. 2002, 17, 685-692, (In Chinese with English Abstract).

4. Rubin, K.H.; Sinton, J.M. Inferences on mid-ocean ridge thermal and magmatic structure from MORB compositions. Earth Planet. Sci. Lett. 2007, 260, 257-276. [CrossRef]

5. Zheng, J.P. Comparison of mantle-derived matierals from different spatiotemporal settings: Implications for destructive and accretional processes of the North China Craton. Chin. Sci. Bull. 2009, 54, 3397-3416. [CrossRef]

6. Tu, K.; Flower, M.F.J; Carlson, R.W.; Xie, G.H.; Chen, C.Y.; Zhang, M. Magmatism in the South China Basin 1. Isotopic and trace-element evidence for an endogenous Dupal mantle component. Chem. Geol. 1992, 97, 47-63. [CrossRef]

7. Schluter, H.U.; Hinz, K.; Block, M. Tectono-stratigraphic terranes and detachment faulting of the South China Sea and Sulu Sea. Mar. Geol. 1996, 130, 39-78. [CrossRef]

8. Yan, Q.S.; Shi, X.F.; Wang, K.S.; Bu, W.R.; Xiao, L. Major element, trace element, and $\mathrm{Sr}$, $\mathrm{Nd}$ and Pb isotope studies of Cenozoic basalts from the South China Sea. Sci. China Ser. D Earth Sci. 2008, 51, 550-566. [CrossRef]

9. Yan, Q.S.; Castillo, P.; Shi, X.F.; Wang, L.L.; Liao, L.; Ren, J.B. Geochemistry and petrogenesis of volcanic rocks from Daimao Seamount (South China Sea) and their tectonic implications. Lithos 2015, 2018-2019, 117-126. [CrossRef]

10. Guan, D.L.; Ke, X.P.; Wang, Y. Basement structures of East and South China Seas and adjacent regions from gravity inversion. J. Asian Earth Sci. 2016, 117, 242-255. [CrossRef]

11. Li, C.-F.; Lin, J.; Kulhanek, D.K.; Expedition 349 Scientists. Proceedings of the International Ocean Discovery Program. Available online: http://publications.iodp.org/proceedings/349/349.PDF (accessed on 18 April 2020).

12. Koppers, A.A.P. On the ${ }^{40} \mathrm{Ar} /{ }^{39} \mathrm{Ar}$ Dating of low-Potassium Ocean Crust Basalt from IODP Expedition 349, South China Sea. Available online: https://ui.adsabs.harvard.edu/abs/2014AGUFM.T31E..03K/abstract (accessed on 18 April 2020).

13. Zhang, L.; He, C.R.; Liu, Y.J.; Lin, J. Frictional properties of the South China Sea oceanic basalt and implications for strength of the Manila subduction seismogenic zone. Mar. Geol. 2017, 394, 16-29. [CrossRef] 
14. Zhang, G.L.; Luo, Q.; Zhao, J.; Jackson, M.G.; Guo, L.S.; Zhong, L.F. Geochemical nature of sub-ridge mantle and opening dynamics of the South China Sea. Earth Planet. Sci. Lett. 2018, 489, 145-155. [CrossRef]

15. Zhang, G.L.; Sun, W.D.; Seward, G. Mantle Source and Magmatic Evolution of the Dying Spreading Ridge in the South China Sea. Geochem. Geophys. Geosyst. 2018, 19, 4385-4399. [CrossRef]

16. Yang, F.; Huang, X.L.; Xu, Y.G.; He, P.L. Plume-ridge interaction in the South China Sea: Thermometric evidence from Hole U1431E of IODP Expedition 349. Lithos 2019, 324, 466-478. [CrossRef]

17. Xu, Y.G.; Wei, J.X.; Qiu, H.N.; Zhang, H.H.; Huang, X.L. Opening and evolution of the South China Sea constrained by studies on volcanic rocks: Preliminary results and a research design. Chin. Sci Bull. 2012, 57, 3150-3164. [CrossRef]

18. Le, B.M.; Yang, T.; Gu, S.Y. Upper mantle and transition zone structure beneath Leizhou-Hainan region: Seismic evidence for a lower-mantle origin of the Hainan plume. J. Asian Earth Sci. 2015, 111, 580-588. [CrossRef]

19. Fan, C.Y.; Xia, S.H.; Zhao, F.; Sun, J.L.; Cao, J.H.; Xu, H.L.; Wan, K.Y. New insights into the magmatism in the northern margin of the South China Sea: Spatial features and volume of intraplate seamounts. Geochem. Geophys. Geosyst. 2017, 18, 2216-2239. [CrossRef]

20. Yang, S.Y.; Fang, N.Q. Geochemical variation of volcanic rocks from the South China Sea and neighboring land: Implication for magmatic process and mantle structure. Acta Oceanol. Sin. 2015, 34, 112-124. [CrossRef]

21. Yan, Q.S.; Straub, S.; Shi, X.F. Hafnium isotopic constraints on the origin of late Miocene to Pliocene seamount basalts from the South China Sea and its tectonic implications. J. Asian Earth Sci. 2019, 171, 162-168. [CrossRef]

22. Fan, J.K.; Zhao, D.P.; Dong, D.D. Subduction of a buoyant plateau at the Manila Trench: Tomographic evidence and geodynamic implications. Geochem. Geophys. Geosyst. 2016, 17, 571-586. [CrossRef]

23. Ding, W.W.; Li, J.B.; Clift, P.D.; IODP Expedition 349 Scientists. Spreading dynamics and sedimentary process of the Southwest Sub-basin, South China Sea: Constraints from multi-channel seismic data and IODP Expedition 349. J. Asian Earth Sci. 2016, 115, 97-113. [CrossRef]

24. Li, C.F.; Xu, X.; Lin, J.; Sun, Z.; Zhu, J.; Yao, Y.J.; Zhao, X.X.; Liu, Q.S.; Kulhanek, D.K.; Wang, J.; et al. Ages and magnetic structures of the South China Sea constrained by deep tow magnetic surveys and IODP Expedition 349. Geochem. Geophys. Geosyst. 2014, 15, 4958-4983. [CrossRef]

25. Chen, Z.X.; Langmuir, C.H. Improving Data Precision and Accuracy with Short-Term and Long-Term Elemental Fractionation Corrections for Non-Matrix Matched Silicate Analysis by LA-ICP-MS. Available online: https://goldschmidtabstracts.info/2018/402.pdf (accessed on 18 April 2020).

26. Xu, N.C.; Shen, J.L.; Zhang, J. Application of X-ray Diffraction, X-ray Fluorescence Spectrometry and Electron Microprobe in the Identification of Basalt. Rock Miner. Anal. 2015, 34, 75-81, (In Chinese with English Abstract).

27. Sun, S.S.; Mcdonough, W.F. Chemical and isotopic systematics of oceanic basalts: Implications for mantle composition and processes. Geol. Soc. Lond. Spec. Publ. 1989, 42,313-345. [CrossRef]

28. Yang, S.Y. Geochemical Characteristics of Basalts from the Daimao Seamount in the South China Sea (SCS) and from the SCS's Neighboring Lands: Implications for the Regional Tectonic Evolution. Ph.D. Thesis, China University of Geosciences, Beijing, China, 17 December 2015. (In Chinese with English Abstract).

29. Jochum, K.P.; Verma, S.P. Extreme enrichment of Sb, $\mathrm{Tl}$ and other trace elements in altered MORB. Chem. Geol. 1996, 130, 289-299. [CrossRef]

30. Jenner, F.E.; O’Neill, H.S.C. Analysis of 60 elements in 616 ocean floor basaltic glasses. Geochem. Geophys. Geosyst. 2012, 13, Q02005. [CrossRef]

31. Li, M. Petrogeochemical characteristics comparison and implications for magmatic processes of the MORBs between EPR and SWIR. Ph.D. Thesis, Ocean University of China, Qingdao, China, 21 May 2014. (In Chinese with English Abstract).

32. Niu, Y.L.; O'Hara, M.J. Origin of ocean island basalts: A new perspective from petrology, geochemistry, and mineral physics considerations. J. Geophys. Res.-Solid Earth 2003, 108, 2209. [CrossRef]

33. Han, Z.Z.; Liu, H.; Li, M.; Sun, X.X.; Lai, Z.Q.; Bian, Y.; Lin, X.H. Mantle Source Featrues of the Basalts and Magma Activity Along the Equatorial Regions in the East Pacific Rise. Period. Ocean. Univ. China 2018, 48, 63-75, (In Chinese with English Abstract).

34. Wang, X.C.; Li, Z.X.; Li, X.H.; Li, J.; Liu, Y.; Long, W.G.; Zhou, J.B.; Wang, F. Temperature, Pressure, and Composition of the Mantle Source Region of Late Cenozoic Basalts in Hainan Island, SE Asia: A Consequence of a Young Thermal Mantle Plume close to Subduction Zones? J. Pet. 2012, 53, 177-233. [CrossRef] 
35. Greenough, J.D.; Dostal, J.; Mallory-Greenough, L.M. Igneous rock associations 5. Oceanic island volcanism II: Mantle processes. Geosci. Can. 2005, 32, 77-90.

36. Furman, T.; Bryce, J.G.; Karson, J.; Iotti, A. East African Rift System (EARS) plume structure: Insights from quaternary mafic lavas of Turkana, Kenya. J. Pet. 2004, 45, 1069-1088. [CrossRef]

37. Yang, S.Y.; Fang, N.Q.; Yang, S.X.; Yao, B.C.; Liang, D.H. A Further Discussion on Formation Background and Tectonic Constraints of Igneous Rocks in Central Sub-Basin of the South China Sea. Earth Sci. J. China Univ. Geosci. 2011, 36, 455-470, (In Chinese with English Abstract).

38. Niu, Y.L.; Batiza, R. An empirical method for calculating melt compositions produced beneath mid-ocean ridges: Application for axis and off-axis (seamounts) melting. J. Geophys. Res.-Solid Earth. 1991, 96, 21753-21777. [CrossRef]

39. Niu, Y.L.; Waggoner, D.G.; Sinton, J.M.; Mahoney, J.J. Mantle source heterogeneity and melting processes beneath seafloor spreading centers: The East Pacific Rise, 18 degrees-19S. J. Geophys. Res. Solid Earth. 1996, 101, 27711-27733. [CrossRef]

40. Choe, W.H.; Lee, J.I.; Lee, M.J.; Hur, S.D.; Jin, Y.K. Origin of E-MORB in a fossil spreading center: The Antarctic-Phoenix Ridge. Geosci. J. 2007, 11, 185-199. [CrossRef]

41. Tian, L.Y.; Castillo, P.R.; Lonsdale, P.; Hahm, D. Petrology and Sr-Nd-Pb-He isotope geochemistry of postspreading lavas on fossil spreading axes off Baja California Sur, Mexico. Geochem. Geophys. Geosyst. 2011, 12. [CrossRef]

42. Hofmann, A.W. Chemical differentiation of the Earth: The relationships between mantle, continental crust, and oceanic crust. Earth Planet. Sci. Lett. 1988, 90, 297-314. [CrossRef]

43. Niu, Y.L.; Collerson, K.D.; Batiza, R.; Wendt, J.I.; Regelous, M. Origin of enriched-type mid-ocean ridge basalt at ridges far from mantle plumes: The East Pacific Rise at $11^{\circ} 20^{\prime}$ N. J. Geophys. Res. Solid Earth 1999, 104, 7067-7087. [CrossRef]

44. Rudnick, R.L.; Fountain, D.M. Nature and composition of the continental crust: A lower crustal perspective. Rev. Geophys. 1995, 33, 267-309. [CrossRef]

45. Hofmann, A.W.; Jochum, K.P.; Seufert, M.; White, W.M. Nb and Pb in oceanic basalts: New constraints on mantle evolution. Earth Planet. Sci. Lett. 1986, 79, 33-45. [CrossRef]

46. Niu, Y.L.; Batiza, R. Trace element evidence from seamounts for recycled oceanic crust in the eastern Pacific mantle. Earth Planet. Sci. Lett. 1997, 148, 471-483. [CrossRef]

47. McLennan, S.M. Relationships between the trace element composition of sedimentary rocks and upper continental crust. Geochem. Geophys. Geosyst. 2001, 2. [CrossRef] 